\title{
Erratum to: Manufacture and biochemical characteristics during ripening of Cheddar cheese with variable $\mathrm{NaCl}$ and equal moisture content
}

\author{
Kirsten Kastberg Møller • Fergal P. Rattray • \\ Erik Høier • Ylva Ardö
}

Published online: 2 October 2012

(C) INRA and Springer-Verlag, France 2012

\section{Erratum to: Dairy Sci. \& Technol. DOI 10.1007/s13594-012-0076-3}

Due to a technical problem arising during the production stage of the above-cited article, Table 5 was not displayed correctly and several other errors were introduced in the text. To rectify these mistakes, we are now reprinting on the following pages, the complete article, as it should have appeared in the original version.

We sincerely apologise to the authors and the readers for any inconvenience caused by the mistakes that appeared in the original version.

The online version of the original article can be found at http://dx.doi.org/10.1007/s13594-012-0076-3.

K. K. Møller • Y. Ardö

Faculty of Science, University of Copenhagen, Rolighedsvej 30, DK-1958 Frederiksberg C, Denmark

K. K. Møller • F. P. Rattray • E. Høier

Chr. Hansen A/S, Bøge Allé 10-12, DK-2970 Hørsholm, Denmark

K. K. Møller $(\square)$

Department of Food Science, Section of Dairy Technology, Faculty of Science, University of Copenhagen, Rolighedsvej 30, DK-1958 Frederiksberg C, Denmark

e-mail:kikm@life.ku.dk 


\title{
Manufacture and biochemical characteristics during ripening of Cheddar cheese with variable $\mathrm{NaCl}$ and equal moisture content
}

\author{
Kirsten Kastberg Møller • Fergal P. Rattray • \\ Erik Høier • Ylva Ardö
}

Received: 22 November 2011 /Revised: 12 May 2012 / Accepted: 14 May 2012

(C) INRA and Springer-Verlag, France 2012

\begin{abstract}
Reduction of salt in ripened cheese presents an industry challenge due to its profound role in flavour and texture development. This study investigated the biochemical impact of varying the salt concentration in Cheddar cheese while maintaining the moisture content constant, with particular emphasis on proteolysis. Cheeses containing $0.9,1.3,1.8$ and $2.4 \%(w / w)$ salt and $37.7 \pm 0.2 \%(w / w)$ moisture were manufactured by parallel adjustment of the curd grain size, cooking temperature and time, cheddaring, curd chip size and rate of salting and analysed over the course of 270 days ripening. Salt reduction affected chymosin and starter lactocepin activities to accelerate casein degradation and accumulate derived peptides at rates correlating positively or

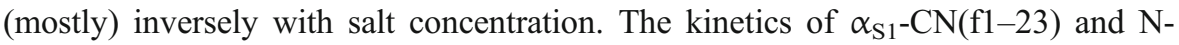
terminal peptides produced thereof and of $\beta-\mathrm{CN}(\mathrm{f} 193-209)$ were studied in detail. Plasmin activity was affected by cooking treatment and (small) $\mathrm{pH}$ differences during ripening but appeared limited overall, due to low levels of $\mathrm{pH}$. Starter lysis showed a strong positive dependency on the salt concentration, and resultant lower contents of free amino acids upon salt reduction were evident. In essence, salt reduction caused a marked decrease in the ratio of peptidase to proteinase activity. Remedies to counterbalance this ratio were discussed in order to avoid excessive accumulation of bitter peptides and promote the stage of maturity. Salt variation left cheese identity unaltered, and the concept of moisture equalisation was proposed as an initial measure to produce high-quality salt-reduced Cheddar.
\end{abstract}

K. K. Møller • Y. Ardö

Faculty of Science, University of Copenhagen, Rolighedsvej 30, DK-1958 Frederiksberg C, Denmark

K. K. Møller · F. P. Rattray • E. Høier

Chr. Hansen A/S, Bøge Allé 10-12, DK-2970 Hørsholm, Denmark

K. K. Møller $(\bowtie)$

Department of Food Science, Section of Dairy Technology, Faculty of Science, University of

Copenhagen, Rolighedsvej 30, DK-1958 Frederiksberg C, Denmark

e-mail: kikm@life.ku.dk 


\section{食盐浓度变化对切达干酪成熟过程中生化特性的影响}

摘要：降低成熟干酪中食盐的含量对干酪的风味和质地有较深远的意义, 因此 该举措目前是工业化生产低盐干酪所面临的一个挑战。该研究考察了切达干 酪在水分含量保持不变的情况下盐浓度的变化对干酪生化特性的影响, 特别强 调蛋白酶解的影响。干酪加工过程中保持水分含量 $37.7 \pm 0.2 \%(w / w)$ 不变, 使干酪食盐含量分别为 $0.9 、 1.3 、 1.8$ 和 $2.4 \%(w / w)$, 调整干酪凝块颗粒大小、 加热温度和时间、凝块碎片大小保持一致, 分析干酪在 $270 \mathrm{~d}$ 的成熟过程中的生 化特性。实验结果表明, 盐浓度的降低影响了凝乳酶和细胞膜蛋白酶的活性从 而加速了酪蛋白的降解和肽的累积, 酪蛋白降解速率与盐浓度的降低呈正相关 或与盐浓度刚好相反。研究了 $\alpha_{\mathrm{S} 1}-\mathrm{CN}(\mathrm{f1}-23) 、 \mathrm{~N}$-末端肽和 $\beta-\mathrm{CN}(\mathrm{f} 193-209)$ 的 动力学。血纤维蛋白溶酶活性在干酪成熟过程中受加热温度和 $\mathrm{pH}$ 的影响, 但是 由于干酪的 $\mathrm{pH}$ 较低, 这种影响不十分明细。发酵剂溶菌的程度依赖食盐的浓 度, 在盐浓度降低时游离氨基酸的净累积量降低。实际上, 盐浓度的降低造成 了肽酶和蛋白酶活的比值显著下降, 弥补了由于这两种酶活比例的不平衡而导 致过多苦味肽形成的问题, 并促进了干酪的成熟。因此, 在实际生产中, 考虑盐 浓度的变化以及水分平衡是生产高质量低盐切达干酪的首要措施。

Keywords Cheddar $\cdot$ Salt reduction $\cdot$ Cheese ripening $\cdot$ Proteolysis

关键词 切达干酪. 盐浓度降低. 干酪成熟. 蛋白酶解

\section{Introduction}

Since the 1960s, a number of national health authorities have advocated and initiated reductions in the human intake of $\mathrm{Na}$ due to the growing evidence of a link between excessive $\mathrm{Na}$ consumption and hypertension (Intersalt 1988). During the past decade, as evidence became conclusive and rates of cardiovascular disease mortality continued to increase, this health concern has gained a strong global momentum, and $\mathrm{Na}$ reduction programmes have been implemented worldwide (Webster et al. 2011).

Cheese is consumed globally in large and increasing quantities and contributes to dietary $\mathrm{Na}$ almost exclusively in the form of $\mathrm{NaCl}$ (salt), which is traditionally added in varying amounts dependent on the cheese variety (Guinee and Fox 2004). Hence, in view of an efficient $\mathrm{Na}$ reduction strategy, cheese, apart from constituting a direct and often daily source of $\mathrm{Na}$, plays an important role in defining the level of salty taste generally accepted by the human perception (taste adaptation). Na reduction of significant magnitudes, however, represents a great challenge to the cheese industry since the level of salting is tightly balanced to take advantage of multiple direct and indirect functions of salt in cheese. Salt has a critical influence on microbial and enzymatic activities needed for a series of biochemical events to proceed in a desired direction during cheese ripening. Thus, the sensory properties of unsalted/salt-reduced Cheddar include increased adhesiveness, cohesiveness, acidity, bitterness and unpleasant aftertaste and a concomitant decrease in firmness and saltiness (Schroeder et al. 1988). Cheese salting, the roles of salt and the general strategies for salt 
reduction in cheese have been reviewed recently (Cruz et al. 2011; Guinee and Fox 2004).

Cheddar represents an important international cheese type, a fairly high source of $\mathrm{Na}$ (typically in the range of 1.6 to $2.0 \%(w / w) \mathrm{NaCl})$ and, consequently, a priority product for $\mathrm{Na}$ reduction. It is therefore not surprising that numerous previous investigations attempted to restore the quality of salt-reduced Cheddar; most commonly by replacing a portion of the added salt in cheese with other chemicals (Cruz et al. 2011). However, this approach may not provide cheese manufacturers with a means to control the microbial growth and biochemistry during ripening and besides, conflicts with an increasing consumer preference for "natural foods". Thus, the challenge of developing strategies that take advantage of technologies and ingredients indigenous to traditional cheese manufacture remains unresolved. In facilitating such solutions, a sound understanding of the influence of salt on the biochemical aspects of ripening is essential. In particular, proteolysis plays a key role in the texture and flavour development of the cheese (Sousa et al. 2001).

Several investigations have been dedicated to elucidating the effect of salt reduction on the ripening of Cheddar and other cheese varieties (Kelly et al. 1996; Rulikowska et al. 2008; Thomas and Pearce 1981). However, one limitation of these studies has been the fact that salt reduction inevitably results in an increased moisture content of the cheese, since salt induces whey syneresis during manufacture. Consequently, while varying the salting rate, the actual experimental range investigated in these studies is expanded as expressed by the salt-in-moisture $(\mathrm{S} / \mathrm{M})$ ratio. The present work aimed to overcome this limitation and investigate the effect of salt on a wide range of metabolic characteristics during ripening of Cheddar cheese, with particular focus on proteolysis. This was approached by developing a cheese-making concept whereby technological parameters could be adjusted in order to vary the salt concentration while keeping the moisture content constant. On the other hand, the moisture equalisation approach may affect other parameters such as plasmin activity, chymosin and Ca phosphate retention as well as the survival and enzymatic activity of the microflora. Hence, potential variance relating to the cheese-making technology rather than the salt concentration was discussed.

\section{Materials and methods}

\subsection{Experimental design}

A cheese-making experiment was designed to investigate the influence of salt on the development of flavour and texture during ripening of full-fat Cheddar cheese. The experimental factor $(S)$ was studied at four levels targeted at $0.8,1.3$, 1.8 and $2.3 \%(w / w)$ salt, which henceforth are referred to as low, reduced, normal and high salt, respectively. Two cheese trials $(T)$ were undertaken on two separate days within one week at the Application and Technology Centre, Chr. Hansen A/S, Hørsholm, Denmark. On each day, four open vats of cheese were manufactured, one 
for each salt level. Hence, the experiment represents a balanced complete block design $(T=2)$ investigating a single experimental factor $(S=4)$ using $N=8$ experimental cheeses. The salt concentration was varied while maintaining the moisture content at 37.0 to $38.0 \%(w / w)$ by parallel adjustment of the curd grain size, cooking temperature and time, cheddaring, curd chip size and rate of salting according to Table 1.

\subsection{Cheddar manufacture and sampling}

Fresh, pasteurised $\left(74{ }^{\circ} \mathrm{C}, 15 \mathrm{~s}\right)$ bovine milk (3.40\% fat, $3.25 \%$ protein) was delivered from Arla Foods Amba (Christiansfeld Mejericenter, Denmark). The milk was standardised to a protein to fat ratio of 0.9 and heated to $32{ }^{\circ} \mathrm{C}\left(31^{\circ} \mathrm{C}\right.$ for low-salt cheese) in the cheese vats containing $150 \mathrm{~kg}$ each. A frozen direct-vat-set multiple-strain starter of Lactococcus lactis was added at a rate of $0.012 \%(w / w)$ (FDVS R-604, Chr. Hansen A/S), and $\mathrm{CaCl}_{2}$ at a rate of $0.01 \%(w / w)$. The milk was coagulated by the addition of $\mathrm{CHY}-\mathrm{MAX}^{\circledR}$ Plus at a rate of $0.018 \%(w / w)$ (204 International Milk-Clotting Units (IMCU) $\cdot \mathrm{mL}^{-1}$; Chr. Hansen A/S). The curd grains were heated to the target temperature over $40 \mathrm{~min}$ and cooked at this temperature for variable lengths of time (Table 1). $\mathrm{pH}$ differences at whey drainage were equalised by adjusting the duration of the cheddaring step to reach a common $\mathrm{pH}$ of 5.2 to 5.3 at milling. Furthermore, during cheddaring, the curd blocks were piled higher and earlier with decreasing salt content (Table 1). The milled curds were dry-salted in a warm vessel by manually mixing approximately half the amount of salt thoroughly into the curd followed by a few minutes rest before mixing in the remaining salt; except for the lowest rate of salting, which was added all at once (Table 1). The salted curds were mixed thoroughly every 5 min over a mellowing period of $20 \mathrm{~min}$. Following moulding, the curds were pre-pressed at $0.20 \mathrm{MPa}$ for $15 \mathrm{~min}$ and then at $0.57 \mathrm{MPa}$ for $17 \mathrm{~h}$. After pressing, each cheese was cut into four equal blocks, which were vacuum-wrapped separately and ripened at $9{ }^{\circ} \mathrm{C}$ until analysis.

One cheese block was used for sampling at day $1\left(t_{1}\right)$ and after $30\left(t_{2}\right), 90\left(t_{3}\right)$ and 270 days $\left(t_{4}\right)$ of ripening (Fig. 1). At each time point of analysis, the triangle denoted

Table 1 Settings of variable technological parameters of cheese-making protocols used for manufacture of full fat Cheddar of variable final salt content and equal final moisture content (37.0 to $38.0 \%(w / w))$

\begin{tabular}{|c|c|c|c|c|c|c|}
\hline $\begin{array}{l}\text { Salt } \\
\text { level }\end{array}$ & $\begin{array}{l}\text { Target salt } \\
(\%(w / w))\end{array}$ & $\begin{array}{l}\text { Curd grain } \\
\text { cutting size } \\
\left(\mathrm{mm}^{3}\right)\end{array}$ & $\begin{array}{l}\text { Cooking } \\
\left({ }^{\circ} \mathrm{C} \times \min \right)\end{array}$ & $\begin{array}{l}\text { Cheddaring }{ }^{\mathrm{b}} \\
\left(\#_{\text {layers }} \times \text { min }\right)\end{array}$ & $\begin{array}{l}\text { Chip size } \\
(L \times W \times T) \\
(\mathrm{cm})\end{array}$ & $\begin{array}{l}\text { Salting rate } \\
(\%(w / w))\end{array}$ \\
\hline Low & 0.8 & 125 & $40.5 \times 45^{\mathrm{a}}$ & $1 \times 25,3 \times 15,3 \times 15,4 \times 15,6 \times 15,6 \times 15$ & $4.0 \times 1.8 \times 2.0$ & 0.95 \\
\hline Reduced & 1.3 & 1,000 & $39.0 \times 20$ & $1 \times 20,2 \times 25,3 \times 30,3 \times 20,4 \times 20$ & $4.0 \times 1.8 \times 2.5$ & 2.60 \\
\hline Normal & 1.8 & 1,000 & $37.0 \times 5$ & $1 \times 20,2 \times 25,3 \times 30,3 \times 15,4 \times 15,6 \times 10$ & $1.7 \times 1.1 \times 3.0$ & 3.70 \\
\hline High & 2.3 & 1,000 & $33.0 \times 5$ & $1 \times 15,2 \times 15,2 \times 20,3 \times 25,3 \times 20,4 \times 10,6 \times 15$ & $1.7 \times 0.7 \times 3.5$ & 4.80 \\
\hline
\end{tabular}

$L$ length, $T$ thickness, $W$ width

${ }^{a}$ The renneting temperature was decreased from 32 to $31{ }^{\circ} \mathrm{C}$ as an additional effort to maximise the temperature gap and hence, the extent of syneresis

${ }^{\mathrm{b}}$ All turning steps are tabulated with the number of curd blocks per pile and the time interval of each turn 
$C$ was sampled aseptically for microbial analysis before it was grated, thoroughly mixed and used for compositional analysis and enzymatic assays. In addition, four portions of grated cheese were vacuum-wrapped and kept at $-50{ }^{\circ} \mathrm{C}$ until analysis of proteolysis, carbohydrates and organic acids.

\subsection{Chemicals}

All chemicals were of analytical grade, and water was purified by deionisation $(18.2 \mathrm{M} \Omega \cdot \mathrm{cm})$ through a MilliQ Plus water system (Millipore, Bedford, MA, USA).

\subsection{Gross compositional analysis and $\mathrm{pH}$}

$\mathrm{NaCl}$ content was determined by automated potentiometric endpoint titration (DL50, Mettler-Toledo A/S, Glostrup, Denmark) (ISO5943:IDF88 2006). Moisture was analysed gravimetrically by drying to a constant weight at $102{ }^{\circ} \mathrm{C}$ (ISO5534:IDF4 2004). Fat and protein (total $\mathrm{N}$ calibration) were determined by near-infrared reflectance spectroscopy using a calibration model based on Cheddar (FoodScan ${ }^{\mathrm{TM}}$ Lab, FOSS, Hillerød, Denmark) (ISO21543:IDF201 2006). pH was measured potentiometrically (pHC2002, Radiometer Analytical SAS, Lyon, France) in a paste prepared by macerating $10 \mathrm{~g}$ of grated cheese in $10 \mathrm{~mL}$ of deionised water. Duplicate samples were analysed at times $t_{1}$ to $t_{4}$ (Fig. 1).

\subsection{Microbiological analysis}

A sample of $10.0 \mathrm{~g}$ was transferred aseptically from the interior of the cheese block to a Stomacher ${ }^{\circledR}$ bag, diluted 1:10 (w/w) with $2 \%(w / v)$ sterile $\mathrm{Na}_{3}$ citrate preheated to $46{ }^{\circ} \mathrm{C}$ and mixed in a Stomacher ${ }^{\circledR}$ blender (4 min, normal speed). Serial 10-fold dilutions were prepared as required in $0.1 \%(w / v)$ peptone/ $0.15 \mathrm{~mol} \cdot \mathrm{L}^{-1} \mathrm{NaCl}$ in water, $\mathrm{pH}$ 7.0. Starter lactic acid bacteria (S-LAB) were enumerated on pour plated M17 agar containing $0.5 \%(w / v)$ lactose (Biokar Diagnostics, Allonne, France) after aerobic incubation for 3 days at $30{ }^{\circ} \mathrm{C}$ and nonstarter lactic acid bacteria (NS-LAB) on pour plated MRS agar (Difco, BD

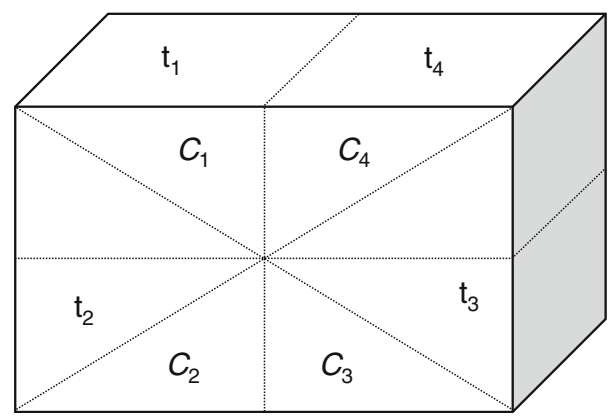

Fig. 1 Sampling procedure within a $15.5 \mathrm{-kg}$ block of Cheddar cheese (not drawn to scale). $t_{1}, t_{2}, t_{3}$ and $t_{4}$, sampling times 1, 30, 90 and 270 days of ripening, respectively; $C_{1}-C_{4}$, compositional analysis at sampling times $t_{1}-t_{4}$ (see text for details) 
Diagnostics, Sparks, MD, USA), pH 5.4, after aerobic incubation for 5 days at $30{ }^{\circ} \mathrm{C}$. Microbial analyses were carried out in duplicate at sampling times $t_{1}$ to $t_{4}$.

\subsection{Analysis of carbohydrates and organic acids}

Carbohydrates and organic acids were quantified by HPLC using a Dionex ICS3000 RFIC-EG ${ }^{\mathrm{TM}}$ dual system equipped with an anion-exchange column eluted at $25{ }^{\circ} \mathrm{C}$ and $0.40 \mathrm{~mL} \cdot \mathrm{min}^{-1}\left(\mathrm{CarboPac}^{\circledR} \mathrm{PA} 20,3 \times 150 \mathrm{~mm}, 6.5 \mu \mathrm{m}\right)$ and an ionexclusion column eluted at $26^{\circ} \mathrm{C}$ and $1.0 \mathrm{~mL} \cdot \mathrm{min}^{-1}$ (IonPac ${ }^{\circledR}$ ICE-AS6, $9 \times 250 \mathrm{~mm}$, $8 \mu \mathrm{m}$ ) for separation of carbohydrates and organic acids, respectively (Dionex, Sunnyvale, CA, USA). Grated cheese $(3.0 \mathrm{~g})$ sampled at times $t_{1}$ to $t_{4}$ (Fig. 1$)$ was rotated for $30 \mathrm{~min}$ at room temperature in $15 \mathrm{~mL}$ of $83 \mathrm{mmol} \cdot \mathrm{L}^{-1}$ perchloric acid containing $2 \mathrm{mmol} \cdot \mathrm{L}^{-1}$ EDTA, $33 \mathrm{mmol} \cdot \mathrm{L}^{-1}$ arabinose and $48 \mathrm{mmol} \cdot \mathrm{L}^{-1}$ 2-hydroxyisobutyric acid (internal standards) with subsequent centrifugation $\left(2,500 \times g, 20 \mathrm{~min}, 4{ }^{\circ} \mathrm{C}\right)$ and filtration of the supernatant $(0.45 \mu \mathrm{m})$. Supernatants were diluted (100-fold) before simultaneous injection into the dual flow path (25 $\mu \mathrm{L}$ for carbohydrates, $50 \mu \mathrm{L}$ for organic acids). For analysis of carbohydrates, the eluent was generated on-line by an EGC II $\mathrm{KOH}$ cartridge module, and stepwise isocratic and linear gradient elution was applied by increasing the $\mathrm{KOH}$ concentration as follows: $19 \mathrm{mmol} \cdot \mathrm{L}^{-1} \mathrm{KOH}$ for $10.5 \mathrm{~min}, 19$ to $100 \mathrm{mmol} \cdot \mathrm{L}^{-1} \mathrm{KOH}$ over $8.5 \mathrm{~min}$, then $\mathrm{kept}$ at $100 \mathrm{mmol} \cdot \mathrm{L}^{-1} \mathrm{KOH}$ for $3.2 \mathrm{~min}$ before re-equilibration at $19 \mathrm{mmol} \cdot \mathrm{L}^{-1} \mathrm{KOH}$ for $14.8 \mathrm{~min}$. Electrochemical detection was used (Dionex). For analysis of organic acids, isocratic elution with $0.4 \mathrm{mmol} \cdot \mathrm{L}^{-1}$ heptafluorobutyric acid and detection by conductivity measurement were applied (Dionex). Concentrations were calculated by relating standardised peak heights to a standard sample.

\subsection{Measurement of plasmin in cheese}

An initial rate kinetic assay was conducted to determine the amount of active plasmin (EC 3.4.21.7) at sampling times $t_{2}$ to $t_{4}$ (Fig. 1) using a modification of the method of Richardson and Pearce (1981). A cheese slurry $(10 \%(w / v))$ was prepared by mixing grated cheese with $2 \%(w / v) \mathrm{Na}_{3}$ citrate preheated to $37^{\circ} \mathrm{C}$ in a Stomacher ${ }^{\circledR}$ blender (5 min, normal speed). The slurry was equilibrated in a $37{ }^{\circ} \mathrm{C}$ water bath for $15 \mathrm{~min}$ and centrifuged $(27,000 \times \mathrm{g}$, $30 \mathrm{~min}, 4^{\circ} \mathrm{C}$ ). The supernatant beneath the fat layer was diluted 6.4 -fold in $50 \mathrm{mmol} \cdot \mathrm{L}^{-1}$ Tris-HCl buffer, $\mathrm{pH} 7.5$, and duplicate aliquots of $160 \mu \mathrm{L}$ were pipetted into a black microtiter plate. Aliquots of substrate solution $(40 \mu \mathrm{L}$ of $1 \mathrm{mmol} \cdot \mathrm{L}^{-1}$ succinyl-Ala-Phe-Lys-7-amino-4-methyl coumarin (Suc-Ala-Phe-LysAMC, cat. no. I-1330, Bachem AG, Bubendorf, Switzerland)) were then added, and immediately after whirling of the plate, the enzymatic cleavage of AMC was followed by measuring fluorescence at $\lambda_{\text {ex/em }}=355 / 460 \mathrm{~nm}$ at $5 \mathrm{~min}$ intervals over an incubation period of $2 \mathrm{~h}$ at $37^{\circ} \mathrm{C}$ (Wallac 1420 Victor $^{2}$, Perkin Elmer, Waltham, MA, USA). The initial rate of AMC release was calculated from the slope of the linear regressions of the sample and an AMC standard curve. Activity was expressed as nmoles of AMC released per minute per gram of cheese at $\mathrm{pH} 7.5$ and $37^{\circ} \mathrm{C}$. 
2.8 Measurement of residual coagulant in cheese

The level of residual chymosin (EC 3.4.23.4) was analysed at sampling times $t_{1}$ to $t_{4}$ (Fig. 1) by measuring the ability of cheese extracts to clot reconstituted skimmed milk according to a method based on Stadhouders et al. (1977). Each sample was extracted four times by homogenising (Heidolph RZR-2000 stirrer equipped with a Teflon piston, $3 \times 1.5 \mathrm{~min}, 300 \mathrm{rpm}) 2.0 \mathrm{~g}$ of grated cheese spiked with $0,40,80$ and $120 \mu \mathrm{L}$ of $2 \mathrm{IMCU} \cdot \mathrm{mL}^{-1} \mathrm{CHY}-\mathrm{MAX}^{\circledR}$ Plus (Chr. Hansen A/S), respectively, with three aliquots of $5 \mathrm{~mL} 1 \mathrm{~mol} \cdot \mathrm{L}^{-1} \mathrm{Na}$ acetate, $\mathrm{pH}$ 4.9. CHY-MAX ${ }^{\circledR}$ Plus was diluted in $\mathrm{Na}$ acetate buffer, $\mathrm{pH} 5.5$, based on the exact activity of the preparation (ISO11815: IDF157 2007). The homogenates were centrifuged $(3,200 \times \mathrm{g}, 10 \mathrm{~min})$, and $3.3 \mathrm{~mL}$ of the supernatant beneath the fat layer was desalted by gel filtration $(\mathrm{MWCO}=6 \mathrm{kDa})$. Reconstituted skimmed milk prepared according to ISO11815:IDF157 (2007) was diluted 10-fold in $19 \mathrm{mmol} \cdot \mathrm{L}^{-1} \mathrm{CaCl}_{2}$, and aliquots of $10.0 \mathrm{~mL}$ were equilibrated for $10 \mathrm{~min}$ in rotating glass tubes placed in a $32{ }^{\circ} \mathrm{C}$ water bath. Each coagulant extract was sampled in duplicate by adding aliquots of $1.0 \mathrm{~mL}$ to the rotating glass tubes. The time (in seconds) at which the first protein flocculates became visible was defined as the clotting time. The amount of residual coagulant was expressed as IMCU per kilogram of cheese, where 1 IMCU was defined according to ISO11815:IDF157 (2007).

\subsection{Measurement of bacterial cell lysis}

Cell autolysis was estimated at sampling times $t_{1}$ to $t_{4}$ (Fig. 1) by assaying for intracellular Gly-Pro dipeptidyl and Lys aminopeptidase (AP) activity in the cheese serum based on Ardö et al. (1989). Grated cheese $(2.0 \mathrm{~g})$ was rotated for $2 \mathrm{~h}$ at $4{ }^{\circ} \mathrm{C}$ in $8.0 \mathrm{~mL}$ of $50 \mathrm{mmol} \cdot \mathrm{L}^{-1}$ Tris $-\mathrm{HCl}, \mathrm{pH} 7.5$, containing $1 \%(w / v)$ BSA. The liquid phase was collected and centrifuged $\left(15,000 \times g, 10 \mathrm{~min}, 4{ }^{\circ} \mathrm{C}\right)$. The supernatant beneath the fat layer was filtered $(0.20 \mu \mathrm{m})$ to remove whole bacterial cells and diluted in cold $50 \mathrm{mmol} \cdot \mathrm{L}^{-1}$ Tris $-\mathrm{HCl} / 1 \%(w / v)$ BSA as required. Triplicate aliquots of $60 \mu \mathrm{L}$ of $0.5 \mathrm{~mol} \cdot \mathrm{L}^{-1}$ Tris- $\mathrm{HCl}, \mathrm{pH} 7.5$ and $30 \mu \mathrm{L}$ of extract were added to a black microtiter plate followed by $10 \mu \mathrm{L}$ of substrate solution $\left(5 \mathrm{mmol} \cdot \mathrm{L}^{-1}\right.$ Gly-Pro-AMC and $5 \mathrm{mmol} \cdot \mathrm{L}^{-1}$ Lys-AMC (cat. no. I-1225 and I-1255, Bachem AG) for Gly-Pro dipeptidyl and Lys AP activity, respectively). The plate was then treated as described in Section 2.7, except that the reaction was followed for $1 \mathrm{~h}$. Activity was expressed as nmoles of AMC released per minute per gram of cheese at $\mathrm{pH} 7.5$ and $37^{\circ} \mathrm{C}$.

\subsection{Assessment of proteolysis}

\subsubsection{Casein degradation}

The casein components were analysed by capillary electrophoresis (CE) at times $t_{1}$ to $t_{4}$ (Fig. 1) (Ardö and Polychroniadou 1999). Grated cheese (10.0 g) was dispersed in $40 \mathrm{~mL}$ of $0.5 \mathrm{~mol} \cdot \mathrm{L}^{-1} \mathrm{Na}_{3}$ citrate by stirring in a $45{ }^{\circ} \mathrm{C}$ water bath for $1 \mathrm{~h}$. Cheese slurries were diluted to $5 \%(w / v)$ and stirred for $5 \mathrm{~min}$. Aliquots of $700 \mu \mathrm{L}$ were mixed 1:1 with CE sample buffer $\left(17 \mathrm{mmol} \cdot \mathrm{L}^{-1}\right.$ DL-dithiothreitol and $2.5 \mathrm{mmol} \cdot \mathrm{L}^{-1}$ Tyr-Ala (internal standard) dissolved in $10 \mathrm{~mol} \cdot \mathrm{L}^{-1}$ urea solution containing 
$0.83 \mathrm{~g} \cdot \mathrm{L}^{-1}$ methyl hydroxypropyl cellulose) in $2.0 \mathrm{~mL}$ micro-centrifuge tubes and incubated at room temperature for $1 \mathrm{~h}$. The fat was removed by centrifugation $\left(2,000 \times g, 30 \mathrm{~min}, 10^{\circ} \mathrm{C}\right)$, and samples were filtered $(0.20 \mu \mathrm{m})$. CE was performed as described previously with minor modifications and peak assignment based on published work (Ardö and Polychroniadou 1999). Integrated peak areas $\left(A_{214} \mathrm{~nm}\right)$ were normalised by dividing with the migration time for semi-quantitative comparison across cheeses. Peak areas of the internal standard showed a standard deviation of $<5 \%$.

\subsubsection{Peptide profiling}

The $\mathrm{pH}$ 4.6-soluble peptides (SP) were analysed by reversed-phase LC-MS/MS using an Agilent 1100 LC/MSD Trap interfaced with Bruker Daltonik software Vers. 5.3 (Trap Control) and 3.3 (Data Analysis) (Agilent Technologies ApS, Hørsholm, Denmark). Samples from times $t_{1}$ to $t_{4}$ (Fig. 1) were prepared according to Ardö and Polychroniadou (1999) from the above-described $5 \%(w / v)$ cheese slurries. Aliquots of $16 \mathrm{~mL}$ were cooled to $12{ }^{\circ} \mathrm{C}$, adjusted to $\mathrm{pH} 4.5$ by adding $1 \mathrm{~mol} \cdot \mathrm{L}^{-1}$ cold $\mathrm{HCl}$ with vigorous mixing and centrifuged $\left(2,000 \times \mathrm{g}, 30 \mathrm{~min}, 5{ }^{\circ} \mathrm{C}\right)$. The supernatants were filtered $(0.20 \mu \mathrm{m})$ and injected $(30 \mu \mathrm{L})$ onto the column (Zorbax $300 \mathrm{SB}-\mathrm{C} 18,2.1 \times 150 \mathrm{~mm}, 5 \mu \mathrm{m}$ ). Binary linear gradient elution at $40{ }^{\circ} \mathrm{C}$ was applied by mixing $0.1 \%(v / v)$ TFA in water (A) with $0.1 \%(v / v)$ TFA in acetonitrile/water $(90: 10(v / v))(B)$ and increasing the concentration of B from 2 to $55 \%(v / v)$ over $60 \mathrm{~min}$, after which the column was purged with $100 \% \mathrm{~B}$ for $6 \mathrm{~min}$ and re-equilibrated at $2 \% \mathrm{~B}$ for $10 \mathrm{~min}$. The flow rate was $0.25 \mathrm{~mL} \cdot \mathrm{min}^{-1}$, and detection was at 210 and $280 \mathrm{~nm}$. Mass spectra were acquired in the positive ion mode with a nebuliser pressure of $345 \mathrm{kPa}$, nitrogen flow of $9 \mathrm{~L} \cdot \mathrm{min}^{-1}$, drying temperature of $300{ }^{\circ} \mathrm{C}$ and scan range $m / z 100$ to 2,200. MS/MS analysis was undertaken for the two most intense ions. The mass of molecular ions $\left(\mathrm{MH}^{+}\right)$was assigned to candidate amino acid sequences (GPMAW Ver. 8.00sr1 (Lighthouse Data, Odense, Denmark), which were then validated by comparing theoretical fragmentation patterns with the recorded MS/MS spectra (MS-Product Ver. 5.7.3, http://prospector.ucsf.edu). Peak areas $\left(A_{210} \mathrm{~nm}\right)$ were used for semi-quantitative comparison across cheeses and the total peak area between 2.5 and $53.0 \mathrm{~min}$ as index of total $\mathrm{pH}$ 4.6-SP.

\subsubsection{Free amino acid composition}

Free amino acid (FAA) concentrations were analysed at sampling times $t_{1}$ to $t_{4}$ (Fig. 1) by reversed-phase HPLC using pre-column derivatisation and fluorometric detection according to the method of Bütikofer and Ardö (1999) with minor modifications.

\subsection{Statistical analysis}

Analysis means of gross compositional constituents were analysed in an additive fixed effects ANOVA model including cheese trial $(T=2)$ as block effect 
(PROC GLM, SAS ${ }^{\circledR}$ Ver. 9.2, SAS Institute, Inc., Cary, NC, USA). A total of thirtythree response variables measured repeatedly during cheese ripening were evaluated from ANOVA of a split-plot model with cheese $(N=8)$ as whole-plot, salt level $(S=4)$ as whole-plot factor, ripening time $(R=4)$ as sub-plot factor and $T$ as random factor. A negative estimate of variance for $T\left(\sigma_{T}^{2}\right)$ was put equal to zero by exclusion from the model, while $\sigma_{N}^{2}<0$ was allowed. When a significant interaction effect $(S \times R)$ was encountered, the main effects were analysed within the non-reduced model by using the technique of slicing (PROC MIXED and PROC GLIMMIX, SAS ${ }^{\circledR}$ Ver. 9.2, SAS Institute, Inc.). Tukey's honestly significant difference $(\alpha=0.05)$ was used as post hoc test for pair-wise comparisons within $S$ and $R$ in all ANOVA models, which were validated by inspection of residual-by-predicted plots, and histograms and quantile plots of the residuals (JMP ${ }^{\circledR}$ Ver. 8.0.1, SAS Institute, Inc.). Additionally, latent structures within the same thirty-three response variables during ripening were modelled by principal components analysis (PCA) using auto-scaling of the data (MATLAB Ver. 7.9.0.529, The MathWorks, Inc., Natick, MA, USA).

\section{Results}

\subsection{Cheese manufacture}

Five principal manufacture parameters comprising curd grain size, cooking temperature and time, cheddaring, curd chip size and rate of salting were varied in parallel according to the specifications of Table 1. As a result, Cheddar cheese containing 0.9, $1.3,1.8$ or $2.4 \%(w / w)$ salt $(P<0.001)$ corresponding to the low, reduced, normal and high salt targets of Table 1 were successfully obtained, while the moisture content was maintained at $37.7 \pm 0.2 \%(w / w)$ across all cheeses $(P=0.3)$ (Table 2$)$. This level of moisture is quite normal relative to the moisture interval typically spanned by Cheddar (35 to $39 \%(w / w))$ (Lawrence et al. 2004). The concept of moisture equalisation caused a $\mathrm{pH}$ decrease from 6.40 to 6.18 at whey drainage $(P<0.001)$ and a decrease in curd syneresis between milling and post-pressing from 22 to $4 \%(w / w)$ with the cheese technology applied at a decreasing level of salt (Table 2). Post-press $\mathrm{pH}$ decreased from 5.20 to 5.01 with decreasing salt content $(P=0.01)$, reflecting a well-recognized inhibitory effect of salt on the starter metabolism (Table 2).

\subsection{Cheese composition}

The four different salt levels manifested in four different ratios of $\mathrm{S} / \mathrm{M}(P<$ 0.001 ), as expected, and first grade Cheddar limits (4.7 to $5.7 \%$ ) were met only for the normal-salt cheese (Table 2) (Lawrence et al. 2004). Ratios of fat-in-dry matter (FDM) and moisture in non-fat substance (MNFS) were comparable across all cheeses. FDM and MNFS ratios were within and slightly higher, respectively, than recommended ranges of first grade Cheddar, of which the latter result was attributable to the level of moisture. The $\mathrm{pH}$ of all 30-day-old cheeses met first grade Cheddar criteria and was higher in high-salt cheese $(P=0.002)$ due to abrupt inhibition of acid production $>6 \% \mathrm{~S} / \mathrm{M}$ (Lawrence et al. 2004). 
Table $2 \mathrm{pH}$ at whey drainage, mass difference between amounts of curds prior to milling and after pressing ( $\Delta$ mass), post-press $\mathrm{pH}$, and gross composition and $\mathrm{pH}$ after 30 days of Cheddar made with variable levels of salt

\begin{tabular}{|c|c|c|c|c|c|c|c|}
\hline \multirow[t]{2}{*}{ Measurement } & \multicolumn{4}{|c|}{ Salt level $(S)$} & \multicolumn{3}{|c|}{ ANOVA } \\
\hline & Low & Reduced & Normal & High & $F$-ratio & $P$-value & HSD \\
\hline $\mathrm{pH}$ at whey drainage & 6.18 & 6.31 & 6.32 & 6.40 & 92 & $<0.001$ & 0.06 \\
\hline$\Delta \operatorname{mass}(\%(w / w))$ & 4.1 & 12.1 & 18.0 & 21.9 & 483 & $<0.001$ & 2.0 \\
\hline Post-press $\mathrm{pH}^{\mathrm{a}}$ & 5.01 & 5.04 & 5.13 & 5.20 & 23 & 0.01 & 0.13 \\
\hline Salt $(\%(w / w))$ & 0.9 & 1.3 & 1.8 & 2.4 & 265 & $<0.001$ & 0.2 \\
\hline Moisture $(\%(w / w))$ & 37.8 & 37.7 & 37.5 & 37.7 & 1.6 & 0.3 & 0.6 \\
\hline Protein $(\%)$ & 24.3 & 24.2 & 24.0 & 23.7 & 48 & 0.001 & 0.2 \\
\hline Fat $^{\mathrm{b}}(\%)$ & 33.7 & 33.4 & 33.3 & 32.9 & 40 & 0.002 & 0.3 \\
\hline $\mathrm{pH}$ & 5.10 & 5.05 & 5.07 & 5.27 & 46 & 0.002 & 0.08 \\
\hline S/M (\%) & 2.3 & 3.5 & 4.8 & 6.3 & 212 & $<0.001$ & 0.7 \\
\hline FDM $(\%)$ & 54.2 & 53.6 & 53.3 & 52.8 & 59 & $<0.001$ & 0.5 \\
\hline MNFS (\%) & 57.1 & 56.7 & 56.3 & 56.1 & 13 & 0.02 & 0.7 \\
\hline
\end{tabular}

FDM fat-in-dry matter, HSD Tukey's honestly significant difference test $(\alpha=0.05), M N F S$ moisture in nonfat substance, $S / M$ salt-in-moisture

${ }^{a}$ Effect of $T(P<0.05) . F_{S} / F_{T}=1.4$

${ }^{\mathrm{b}}$ Effect of $T(P<0.05)$. The effect was insignificant as compared to $S\left(F_{S} / F_{T}=11\right)$ and hence, removed from the model

\subsection{Microbial viability}

The S-LAB counts at day 1 were similar across all cheeses $\left(>9 \log \mathrm{cfu}^{-1}{ }^{-1}\right)$ regardless of the salt concentration (Table 3). Evidently, the high thermal stress conditions $\left(40.5{ }^{\circ} \mathrm{C} \times 45 \mathrm{~min}\right)$ and the high level of salt $(4.8 \%(w / w))$ used for the manufacture of low- and high-salt cheeses, respectively, had no effect on the early S-LAB counts reflecting a marked robustness of the starter culture. NSLAB counts across all cheeses during ripening were lower than what would typically be expected for Cheddar cheese. This is probably due to the fact that the enumeration method (aerobic incubation) was not sensitive enough to detect the entire NS-LAB flora present. Nevertheless, it appears that the low-salt cheese supported somewhat higher NS-LAB counts, which agrees with previous reports (Rulikowska et al. 2008).

\subsection{Carbohydrates and organic acids}

In agreement with post-press $\mathrm{pH}$ differences, residual lactose was rapidly metabolised in low- and reduced-salt cheeses (Table 4). Conversely, high-salt cheese contained $18 \mathrm{mmol}$ lactose per kilogram post-press, corresponding to a level somewhat below that of typical Cheddar curd at milling (McSweeney and Fox 2004); this level remained virtually constant for the entire ripening period. A similar effect on starter metabolism has been reported between 4 and $6 \% \mathrm{~S} / \mathrm{M}$, and while residual lactose may persist for several months in cheese with 6 to $7 \% \mathrm{~S} / \mathrm{M}$, it is typically utilised by 
Table 3 Microbial viability (log $\left.\mathrm{cfu} \cdot \mathrm{g}^{-1}\right)$ in Cheddar made with a low $(0.9 \%)$, reduced $(1.3 \%)$, normal $(1.8 \%)$ or high $(2.4 \%)$ level of salt

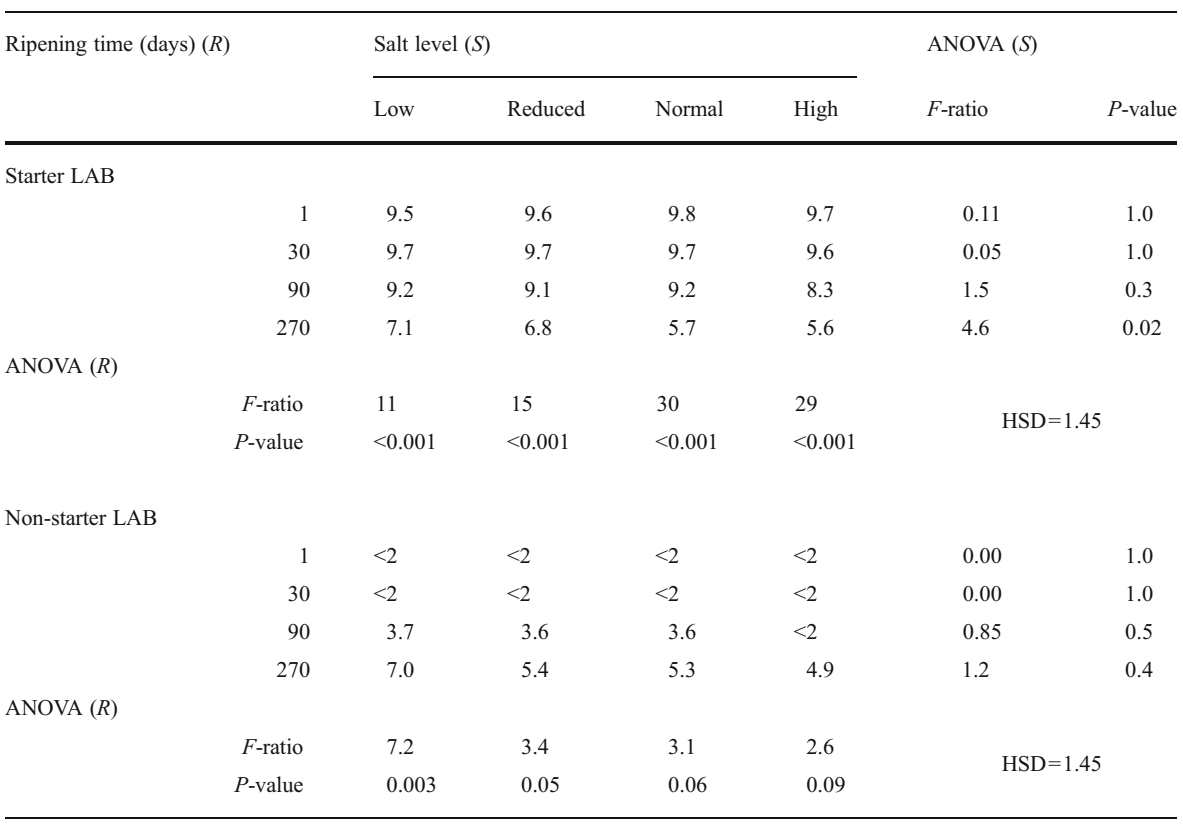

$L A B$ lactic acid bacteria, $H S D$ Tukey's honestly significant difference test $(\alpha=0.05)$

NS-LAB eventually (Thomas and Pearce 1981). Lactose and lactate levels correlated inversely post-press and during early ripening, as expected (not shown). Once formed, the total pool of lactate remained constant during ripening at all salt levels (Table 4), which is not unusual in Cheddar cheese where a low redox potential exists (McSweeney and Fox 2004; Thomas and Pearce 1981). As a (partial) consequence, only a weak $\mathrm{pH}$ increase was measured during ripening $(P=0.002)$ (Table 4$)$. The amount of citrate changed during ripening $(P<0.001)$ independent of the salt concentration $(P=0.1)$ (Table 4$)$. The fresh cheeses contained about $10 \mathrm{mmol}$ citrate per kilogram, which was partly utilised during early ripening followed by a slight, yet statistically significant increase in citrate concentration by the end of ripening (Table 4). All citrate levels were in line with typical Cheddar cheese (McSweeney and Fox 2004).

\subsection{Plasmin, chymosin and aminopeptidase activities}

The amount of active plasmin measured in low-salt cheeses was higher than in the others, which all showed similar activities $(P<0.001)$ (Table 4$)$. This difference manifested in slightly higher amounts of derived $\gamma_{1}$-casein $(\mathrm{CN}), \gamma_{3}-\mathrm{CN}$ (not shown) and $\beta-\mathrm{CN}(\mathrm{fl}-28)(P<0.001)$ during early ripening of low-salt cheese as compared to the rest. This may reflect the elevated cooking treatment applied for low-salt cheese manufacture. However, the opposite effect was observed during later ripening (not shown), suggesting that the higher $\mathrm{pH}$ of high-salt cheese governed plasmin activity at that stage. All plasmin activities corresponded well with previous extracts from Cheddar (Richardson and Pearce 1981). 
Table 4 Various biochemical variables measured during ripening of Cheddar made with a low $(0.9 \%)$, reduced $(1.3 \%)$, normal $(1.8 \%)$ or high $(2.4 \%)$ level of salt

\begin{tabular}{|c|c|c|c|c|c|c|c|}
\hline \multirow[t]{4}{*}{ Measurement } & \multicolumn{4}{|c|}{ Salt level $(S)$} & \multirow{2}{*}{\multicolumn{3}{|c|}{$\begin{array}{l}\text { ANOVA }(S) \\
\text { ANOVA }(R)\end{array}$}} \\
\hline & \multicolumn{4}{|c|}{ Ripening time $(R)$} & & & \\
\hline & Low & Reduced & Normal & High & \multirow{2}{*}{$F$-ratio } & \multirow[t]{2}{*}{$P$-value } & \multirow[t]{2}{*}{ HSD } \\
\hline & 1 day & 30 days & 90 days & 270 days & & & \\
\hline \multirow[t]{2}{*}{$\mathrm{pH}$} & 5.10 & 5.06 & 5.12 & 5.29 & 93 & 0.002 & 0.07 \\
\hline & 5.09 & 5.12 & 5.16 & 5.20 & 6.8 & 0.002 & 0.07 \\
\hline \multirow[t]{2}{*}{ Lactose $\left(\mathrm{mmol} \cdot \mathrm{kg}^{-1}\right)$} & 1.0 & 2.3 & 7.1 & 18 & 293 & $<0.001$ & 2.8 \\
\hline & 12 & 5.6 & 6.2 & 5.2 & 17 & $<0.001$ & 2.8 \\
\hline \multirow[t]{2}{*}{ Lactate $\left(\mathrm{mmol} \cdot \mathrm{kg}^{-1}\right)$} & 156 & 155 & 136 & 97 & 168 & $<0.001$ & 12 \\
\hline & 119 & 142 & 139 & 145 & 13 & $<0.001$ & 12 \\
\hline \multirow[t]{2}{*}{ Citrate $^{\mathrm{a}}\left(\mathrm{mmol} \cdot \mathrm{kg}^{-1}\right)$} & 8.5 & 8.7 & 8.4 & 8.6 & 3.6 & 0.1 & 0.5 \\
\hline & 10.1 & 8.5 & 7.3 & 8.3 & 92 & $<0.001$ & 0.5 \\
\hline \multirow[t]{2}{*}{ Plasmin $\left(\mathrm{nmol} \cdot \mathrm{min}^{-1} \cdot \mathrm{g}^{-1}\right)$} & 1.1 & 0.94 & 0.91 & 0.93 & 172 & $<0.001$ & 0.03 \\
\hline & n.a. & 0.94 & 1.1 & 0.89 & 155 & $<0.001$ & 0.03 \\
\hline \multirow[t]{2}{*}{ Chymosin (IMCU $\left.\cdot \mathrm{kg}^{-1}\right)$} & 33 & 33 & 32 & 38 & 6.6 & 0.05 & 4 \\
\hline & 34 & 35 & 32 & 34 & 1.5 & 0.2 & 4 \\
\hline \multirow[t]{2}{*}{$\alpha_{\mathrm{S} 1}-\mathrm{CN}(8 P+9 P)^{\mathrm{b}}(\mu \mathrm{AU})$} & 220 & 233 & 244 & 255 & 37 & 0.002 & 19 \\
\hline & 624 & 228 & 76 & 24 & 2,665 & $<0.001$ & 19 \\
\hline \multirow[t]{2}{*}{$\alpha_{\mathrm{S} 1}-\mathrm{I}-\mathrm{CN}(8 P)^{\mathrm{b}}(\mu \mathrm{AU})$} & 115 & 102 & 99 & 103 & 46 & 0.005 & 11 \\
\hline & 39 & 177 & 159 & 43 & 564 & $<0.001$ & 11 \\
\hline \multirow[t]{2}{*}{$\alpha_{\mathrm{S} 1-\mathrm{CN}}(\mathrm{f} 102-199)^{\mathrm{b}}(\mu \mathrm{AU})$} & 72 & 82 & 87 & 94 & 703 & $<0.001$ & 11 \\
\hline & 16 & 50 & 104 & 165 & 417 & $<0.001$ & 11 \\
\hline \multirow[t]{2}{*}{$\beta-\mathrm{CN}^{\mathrm{A} 1+\mathrm{A} 2 \mathrm{a}}(\mu \mathrm{AU})$} & 561 & 594 & 620 & 636 & 60 & 0.004 & 24 \\
\hline & 770 & 705 & 577 & 358 & 810 & $<0.001$ & 24 \\
\hline \multirow[t]{2}{*}{ para $-\mathrm{K}-\mathrm{CN}^{\mathrm{b}}(\mu \mathrm{AU})$} & 143 & 151 & 158 & 164 & 22 & 0.006 & 13 \\
\hline & 175 & 172 & 147 & 122 & 47 & $<0.001$ & 13 \\
\hline \multirow[t]{2}{*}{$\alpha_{\mathrm{S} 2}-\mathrm{CN}(x P+x P)(\mu \mathrm{AU})$} & 71 & 73 & 71 & 77 & 21 & 0.02 & 6 \\
\hline & 106 & 80 & 59 & 47 & 292 & $<0.001$ & 6 \\
\hline \multirow[t]{2}{*}{$\beta-\mathrm{CN}(\mathrm{fl}-28)^{\mathrm{b}}(\mathrm{AU} \cdot \mathrm{s})$} & 1.5 & 1.2 & 1.1 & 1.1 & 67 & $<0.001$ & 0.1 \\
\hline & 1.0 & 1.2 & 1.4 & 1.2 & 29 & $<0.001$ & 0.1 \\
\hline \multirow[t]{2}{*}{$\mathrm{pH} 4.6-\mathrm{SP}^{\mathrm{b}}(\mathrm{AU} \cdot \mathrm{s})$} & 81 & 78 & 73 & 67 & 1,226 & $<0.001$ & 4 \\
\hline & 21 & 58 & 85 & 136 & 1,666 & $<0.001$ & 4 \\
\hline
\end{tabular}

$C N$ casein, $H S D$ Tukey's honestly significant difference test $(\alpha=0.05)$, n.a. not analysed, $p H$ 4.6-SP index of total $\mathrm{pH}$ 4.6-soluble peptides

${ }^{a}$ Weak effect of $S \times R$ for citrate: $F=2.7 ; P=0.06$ and $\beta-\mathrm{CN}^{\mathrm{A} 1+\mathrm{A} 2}: F=2.7, P=0.05$ was removed from the model in the absence of systematism and because it was negligible compared to the main effects, respectively

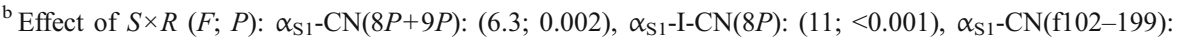
$(16 ;<0.001)$, para-k-CN: $(3.1 ; 0.04), \beta-\mathrm{CN}(\mathrm{fl} 1-28)$ : $(3.3 ; 0.03)$ and $\mathrm{pH} 4.6-\mathrm{SP}:(3.4 ; 0.03)$. The effect was negligible, small and/or unsystematic compared to the main effects and hence, removed from the model

In agreement with earlier findings (Bansal et al. 2009a), about $10 \%$ of chymosin added to the cheese milk was retained across all cheeses $(P=0.05)$, suggesting that variation in $\mathrm{pH}$ at whey drainage across the different cheese technologies did not 
significantly influence the level of chymosin retention in the cheeses (Tables 2 and 4). Once retained in the cheeses, the activity of chymosin remained constant throughout ripening $(P=0.2)$.

A strong effect of salt concentration on Lys and especially Gly-Pro dipeptidyl AP activities was observed after 30, 90 and 270 days $(P<0.001)$, which indicated a positive relationship between the levels of $\mathrm{S} / \mathrm{M}$ and starter lysis (Fig. 2). Likewise, AP activities measured in the cheese serum were markedly promoted by ripening time at all salt levels $(P=0.02$ to $<0.001)$, as expected. However, the use of X-Pro dipeptidyl AP as marker enzyme of cell lysis in cheese has yet to be evaluated unequivocally (Rulikowska et al. 2008; Wilkinson et al. 1994).

\subsection{Casein degradation}

Casein breakdown during ripening was monitored by CE. Overall, little qualitative impact of the salt concentration was displayed, whereas the rate of casein breakdown and formation of major casein fragments were affected by salt to varying extents. Degradation of $\alpha_{\mathrm{S} 1}-\mathrm{CN}$ proceeded rapidly during early ripening for all cheeses, yet at an increasing rate with decreasing salt content $(P=0.002)$ (Table 4$)$, as observed for $\mathrm{S} /$ $\mathrm{M}$ (Kelly et al. 1996). On average, less than $15 \% \alpha_{\mathrm{S} 1}-\mathrm{CN}$ was left intact after 90 days, and degradation continued to approximate completion at the end of ripening $(P<0.001)$. A parallel rapid formation of $\alpha_{\mathrm{S} 1}-\mathrm{I}-\mathrm{CN}$ at all salt levels $(P<0.001)$ and at a rate inversely correlated with salt concentration (not shown) ascribed much of the initial $\alpha_{\mathrm{S} 1}-\mathrm{CN}$ degradation to primary chymosin activity $\left(\alpha_{\mathrm{S} 1}-\mathrm{CN}_{23 / 24}\right)$ irrespective of the salt concentration. $\alpha_{\mathrm{S} 1}-\mathrm{I}-\mathrm{CN}$ concentrations peaked during early ripening and

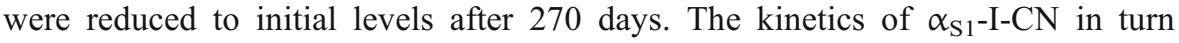
matched the steady, distinct accumulation of a peak tentatively assigned to $\alpha_{\mathrm{S} 1}-\mathrm{CN}$

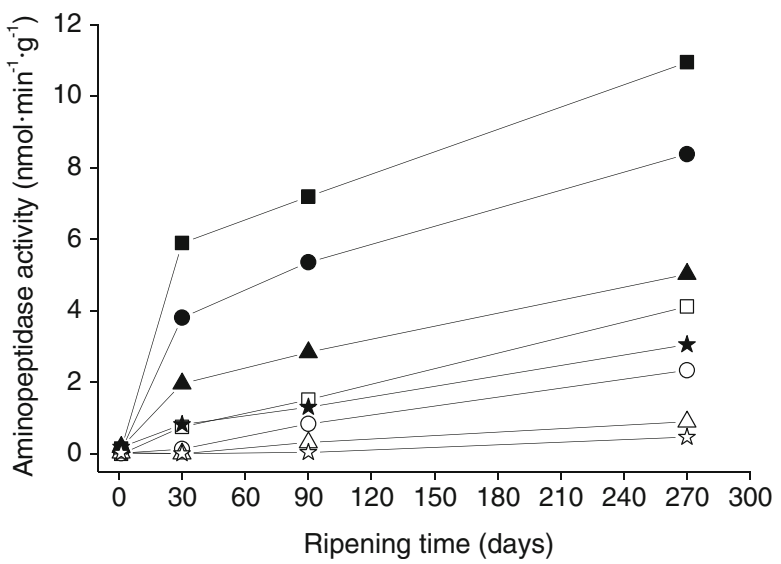

Fig. 2 Activity of aminopeptidases (AP) with Gly-Pro dipeptidyl (closed symbols) and Lys (open symbols) specificity measured in cheese serum during ripening of Cheddar made with a low $(0.9 \%)$ (star), reduced $(1.3 \%)$ (triangle), normal (1.8\%) (circle) or high (2.4\%) (square) level of salt. Each data point represents the mean of duplicate cheese trials. The effect of salt and ripening time on both activities was significant at $P<0.001$ after 30, 90 and 270 days and at all salt levels, respectively, except for Lys AP at the low salt level $(P=0.02)$. HSD $=1.2$ and $0.46 \mathrm{nmol} \cdot \mathrm{min}^{-1} \cdot \mathrm{g}^{-1}$ for Gly-Pro dipeptidyl and Lys AP, respectively 
(f102-199) throughout ripening of all cheeses $(P<0.001)$, yet at a rate positively correlated with salt concentration $(P<0.001)$ (Kelly et al. 1996). Chymosin preference to $\alpha_{\mathrm{S} 1}-\mathrm{CN}_{23 / 24}$ followed by $\alpha_{\mathrm{S} 1}-\mathrm{CN}_{101 / 102}$ cleavage is typical in Cheddar (Sousa et al. 2001).

$\beta-\mathrm{CN}$ proved much more resistant to hydrolysis than $\alpha_{\mathrm{S1}}-\mathrm{CN}$, as expected, due to its pronounced hydrophobicity. On average, about $50 \%$ of the $\beta-\mathrm{CN}$ remained intact after 270 days $(P<0.001)$, while the rate of $\beta-\mathrm{CN}$ hydrolysis increased with decreasing salt concentration $(P=0.004)$ (corresponding to an $8 \%$ difference between lowand normal-salt cheeses) (Table 4 ) in agreement with previous effects reported of S/M in Cheddar cheese (Kelly et al. 1996). Concomitant net accumulation of the $\gamma$-CNs confirmed that plasmin contributed to $\beta-\mathrm{CN}$ degradation during ripening (not shown), but the observed effects of salt suggested that proteinases other than plasmin governed $\beta-\mathrm{CN}$ degradation as supported by a generally limited level of plasmin activity in cheese below pH 5.4 (Larsson et al. 2006).

Chymosin coagulation of the milk efficiently converted $\mathrm{k}-\mathrm{CN}$ to para-k-CN, the further hydrolysis of which was significant during ripening $(P<0.001)$ and inversely correlated with salt concentration $(P=0.006)$. After 270 days of ripening, an estimated 45 and $19 \%$ of post-press para-K-CN were degraded in the low- and high-salt cheeses, respectively (not shown). Para-k-CN has been reported to be very resistant to hydrolysis during ripening (Sousa et al. 2001). At least two fractions of $\alpha_{\mathrm{S} 2}-\mathrm{CN}$ were observed by $\mathrm{CE}$ analysis, both of which were gradually hydrolysed $(P<0.001)$. A slightly slower degradation was indicated at the highest salt level $(P=0.02)$ (Table 4$)$.

\subsection{Peptide formation and degradation}

Representative chromatographic profiles of all cheese samples are shown in Fig. 3 with peaks assigned by MS/MS at days 1 and 30 according to Table 5. In general, identification priority was given to peaks displaying an effect of salt and which were dominated by one or a few peptides. Among the eighty peptides identified after 30 days following this strategy, thirty-three, thirty-one, fifteen and one peptide(s) originated from $\alpha_{\mathrm{S} 1^{-}}, \beta-, \alpha_{\mathrm{S} 2^{-}}$and $\mathrm{k}-\mathrm{CN}$, respectively. The vast majority of these peptides were present already at day 1 . Suggested enzyme activities responsible for their formation are summarised in Table 5. The index of total $\mathrm{pH} 4$.6-SP suggested an inverse correlation with salt concentration $(P<0.001)$ and a positive correlation with ripening time $(P<0.001)$ (Table 4$)$, both of which trends agree with previous observations in Cheddar cheese (Kelly et al. 1996). Indeed, the concentration of the majority of identified peptides showed an inverse dependency on the level of salt (Table 5).

In accordance with casein degradation patterns, peptide profiling indicated that salt affected the activity rather than specificity of responsible enzymes. Activity differences were in turn apparent for most chromatographic peaks. Thus, irrespective of salt concentration, the very earliest and most prominent developing peaks contained $\alpha_{\mathrm{S} 1}-\mathrm{CN}(\mathrm{f1}-9 / 13)(\mathrm{E} / \mathrm{I}), \beta-\mathrm{CN}(1-28)(\mathrm{AD})$ and proteose peptones (AW-A $\left.\mathrm{E}\right)$, and $\beta-$ $\mathrm{CN}(193-209)$ (AT), representing lactococcal cell envelope-associated proteinase (CEP, lactocepin), plasmin and chymosin activity, respectively (Fig. 3, 1 day panel). Day 1 concentrations of the N-terminal peptide of primary chymosin cleavage of $\alpha_{\mathrm{S}^{-}}$$\mathrm{CN}, \alpha_{\mathrm{S} 1}-\mathrm{CN}(\mathrm{fl}-23)(\mathrm{AN})$ appeared considerably lower than initial CEP-derived peptides, which in combination with the rapid accumulation of $\alpha_{\mathrm{S} 1}$-I-CN confirms 


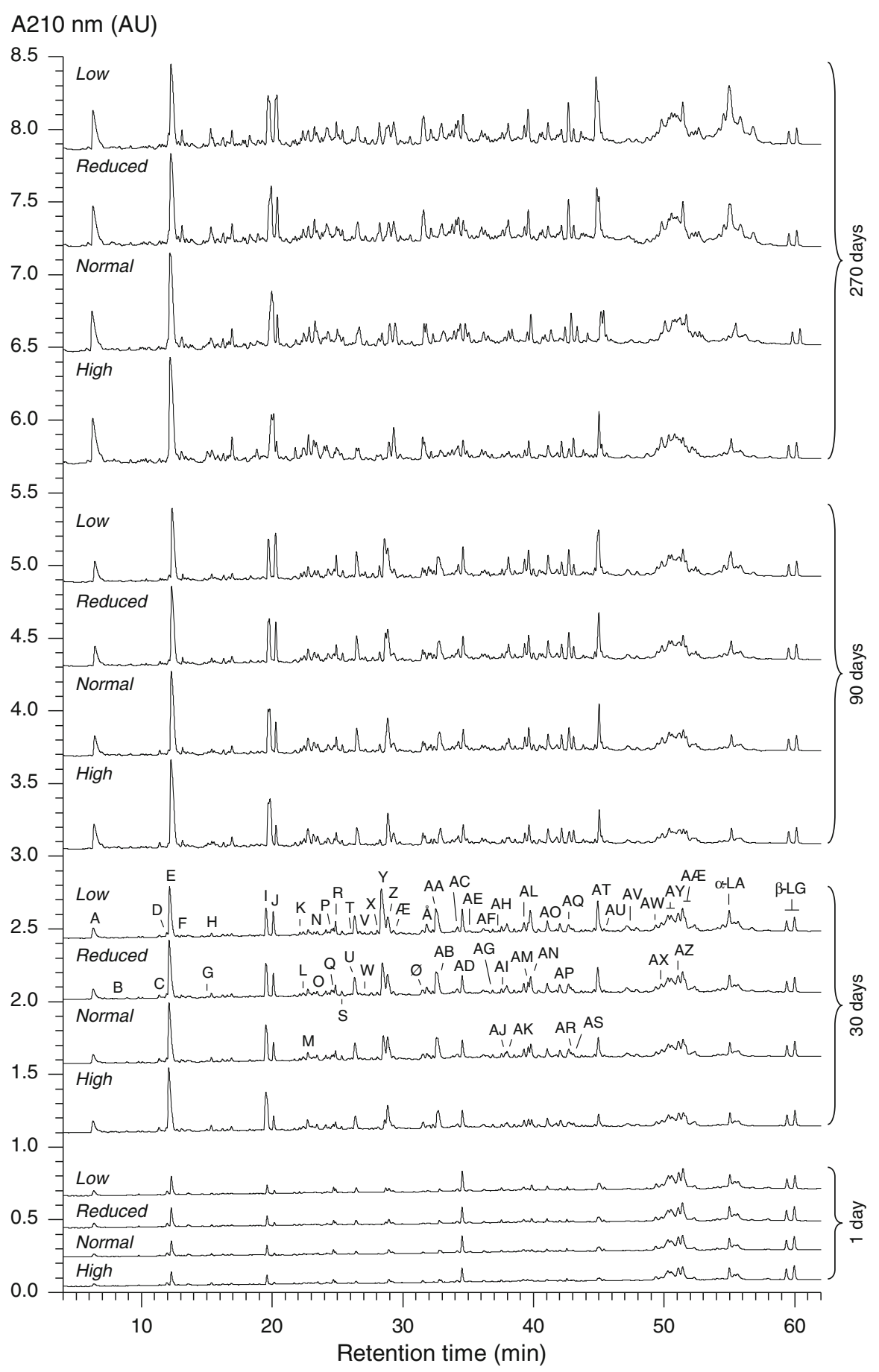

Fig. 3 Reversed-phase HPLC profiles $\left(A_{210} \mathrm{~nm}\right)$ of $\mathrm{pH}$ 4.6-soluble peptides extracted from Cheddar made with a low (0.9\%), reduced (1.3\%), normal (1.8\%) and high (2.4\%) level of salt after 1, 30, 90 and 270 days of ripening. Peptide peaks denoted by capital letter were identified by LC-MS/MS as specified in Table 5 
Table 5 LC-MS/MS results of eighty $\mathrm{pH}$ 4.6-soluble peptides produced during early ripening of Cheddar made with $0.9,1.3,1.8$ or $2.4 \%$ salt

\begin{tabular}{|c|c|c|c|c|c|c|c|}
\hline \multirow[t]{2}{*}{ Peak $^{\mathrm{a}}$} & \multirow[t]{2}{*}{$\mathrm{RT}^{\mathrm{a}}(\min )$} & \multicolumn{2}{|l|}{ Mass (Da) } & \multirow[t]{2}{*}{ Assigned peptide } & \multicolumn{2}{|c|}{ Salt reduction ${ }^{c}$} & \multirow[t]{2}{*}{ Suggested activity ${ }^{\mathrm{f}}$} \\
\hline & & Observed & Calculated & & 1 days & 30 days & \\
\hline \multirow[t]{2}{*}{ A } & $6.1-7.0$ & 119.0 & 165.2 & Phe & $\uparrow$ & - & \\
\hline & & 445.4 & 445.6 & $\beta-\mathrm{CN}(\mathrm{f} 102-105)$ & & & $\mathrm{CEP}_{101 / 102}{ }^{\mathrm{g}} ; \mathrm{PLA}_{105 / 106^{\mathrm{g}}}$ \\
\hline B & $7.7-8.1$ & 287.3 & 287.4 & $\alpha_{\mathrm{S} 1}-\mathrm{CN}(\mathrm{f} 21-22 / 99-100)$ & n.d. & $\downarrow$ & $\mathrm{PepO} / \mathrm{CHY}_{20 / 21}{ }^{\mathrm{h}, \mathrm{i}} ; \mathrm{CHY} / \mathrm{CEP}_{98 / 99}{ }^{\mathrm{g}}$ \\
\hline $\mathrm{C}$ & $11.2-11.5$ & 473.2 & 473.5 & $\alpha_{\mathrm{S} 1}-\mathrm{CN}(\mathrm{f} 14-17)$ & n.d. & $\downarrow$ & $\mathrm{CEP}_{13 / 14^{\mathrm{g}}} ; \mathrm{CEP}_{17 / 18^{\mathrm{g}}}$ \\
\hline $\mathrm{D}$ & $11.8-12.0$ & 416.4 & 416.5 & $\beta-\mathrm{CN}(\mathrm{fl}-3)$ & n.d. & $\uparrow$ & $\mathrm{CHY}_{3 / 4}{ }^{\mathrm{j}}$ \\
\hline \multirow[t]{2}{*}{$\mathrm{E}$} & $12.0-12.5$ & 1140.0 & 1140.4 & $\alpha_{\mathrm{S} 1-\mathrm{CN}(\mathrm{fl}-9)}$ & $\uparrow$ & $\downarrow$ & $\mathrm{CEP}_{9 / 10}{ }^{\mathrm{g}}$ \\
\hline & & 1012.0 & 1012.2 & $\alpha_{\mathrm{S} 1}-\mathrm{CN}(\mathrm{fl} 1-8)(m)$ & & & $\mathrm{CEP}_{8 / 9}{ }^{\mathrm{g}}$ \\
\hline $\mathrm{F}$ & $12.6-12.9$ & 875.1 & 875.1 & $\alpha_{\mathrm{S} 1}-\mathrm{CN}(\mathrm{f} 1-7)$ & - & - & \\
\hline G & $14.9-15.1$ & 578.4 & 578.7 & $\alpha_{\mathrm{S} 1}-\mathrm{CN}(\mathrm{f} 31-35)$ & n.d. & $\downarrow$ & $\mathrm{CEP}_{35 / 36}{ }^{\mathrm{k}}$ \\
\hline \multirow[t]{6}{*}{$\mathrm{H}$} & $15.2-15.5$ & 542.4 & 542.6 & $\alpha_{\mathrm{S} 1}-\mathrm{CN}(\mathrm{f} 10-14)$ & $\downarrow$ & $\downarrow$ & $\mathrm{CEP}_{9 / 10}{ }^{\mathrm{g}} ; \mathrm{PepO}_{14 / 15}{ }^{\mathrm{h}}$ \\
\hline & & 678.8 & 678.8 & $\alpha_{\mathrm{S} 1}-\mathrm{CN}(\mathrm{f8}-13)(m)$ & & & $\mathrm{CEP}_{13 / 14^{\mathrm{g}}}$ \\
\hline & & 806.6 & 806.9 & $\alpha_{\mathrm{S} 1}-\mathrm{CN}(\mathrm{f} 7-13)$ & & & $\mathrm{CEP}_{13 / 14^{\mathrm{g}}}$ \\
\hline & & 746.6 & 746.9 & $\alpha_{\mathrm{S} 1}-\mathrm{CN}(\mathrm{f} 1-6)$ & & & \\
\hline & & 633.7 & 633.8 & $\alpha_{\mathrm{S} 1}-\mathrm{CN}(\mathrm{f} 56-60)(m)$ & & & $\mathrm{CEP}_{60 / 61}{ }^{\mathrm{k}}$ \\
\hline & & 1001.0 & 1001.3 & $\beta-\mathrm{CN}(\mathrm{f} 97-105)$ & & & $\mathrm{PLA}_{105 / 106^{\mathrm{g}}}$ \\
\hline \multirow[t]{2}{*}{ I } & $19.4-19.8$ & 1536.0 & 1535.8 & $\alpha_{\mathrm{S} 1-\mathrm{CN}(\mathrm{fl} 1-13)}$ & - & $\downarrow$ & $\mathrm{CEP}_{13 / 14^{g}}$ \\
\hline & & 1244.7 & 1244.5 & $\beta-\mathrm{CN}(\mathrm{f} 94-105)(m)$ & & & $\mathrm{CHY} / \mathrm{CEP}_{93 / 94}{ }^{1, \mathrm{~g}} ; \mathrm{PLA}_{105 / 106}{ }^{\mathrm{g}}$ \\
\hline \multirow[t]{2}{*}{$\mathrm{J}$} & $20.0-20.3$ & 1664.9 & 1664.9 & $\alpha_{\mathrm{S} 1-\mathrm{CN}(\mathrm{fl}-14)}$ & $\uparrow$ & $\uparrow$ & $\mathrm{PepO}_{14 / 15}{ }^{\mathrm{h}}$ \\
\hline & & 757.7 & 757.8 & $\alpha_{\mathrm{S} 1}-\mathrm{CN}(\mathrm{f} 17-22)(m)$ & & & $\mathrm{CEP}_{16 / 17^{g}}$ \\
\hline $\mathrm{K}$ & $22.0-22.2$ & 2355.4 & 2355.1 & $\alpha_{\mathrm{S} 2}-\mathrm{CN}(\mathrm{f} 1-18) 4 \mathrm{P}$ & $\uparrow$ & $\uparrow$ & \\
\hline \multirow[t]{2}{*}{$\mathrm{L}$} & $22.2-22.6$ & 549.8 & 549.7 & $\alpha_{\mathrm{S} 2-\mathrm{CN}(\mathrm{f} 204-207)}$ & $\downarrow$ & - & $\mathrm{CEP}_{203 / 204}{ }^{\mathrm{g}}$ \\
\hline & & 855.8 & 855.9 & $\beta-\mathrm{CN}(\mathrm{f} 7-14)$ & & & $\mathrm{CHY} / \mathrm{CEP}_{6 / 7}{ }^{\mathrm{j}, \mathrm{g}}$ \\
\hline \multirow[t]{2}{*}{ M } & $22.6-22.9$ & 601.5 & 601.7 & $\alpha_{\mathrm{S} 1}-\mathrm{CN}(\mathrm{f} 17-21)$ & $\downarrow$ & $\downarrow$ & $\mathrm{CEP}_{16 / 17^{\mathrm{g}}} ; \mathrm{CEP}_{21 / 22}{ }^{\mathrm{g}}$ \\
\hline & & 2143.6 & 2143.9 & $\alpha_{\mathrm{S} 2-\mathrm{CN}(\mathrm{f} 6-21) 4 \mathrm{P}}$ & & & $\mathrm{PLA}_{21 / 22}{ }^{\mathrm{g}}$ \\
\hline \multirow[t]{2}{*}{$\mathrm{N}$} & $23.2-23.4$ & 400.6 & 400.5 & $\alpha_{\mathrm{S} 1}-\mathrm{CN}(\mathrm{f} 99-101)$ & $\downarrow$ & - & $\mathrm{CHY} / \mathrm{CEP}_{98 / 99^{\mathrm{g}}} ; \mathrm{CHY}_{101 / 102^{\mathrm{g}}}$ \\
\hline & & 997.2 & 997.3 & $\beta-\mathrm{CN}(\mathrm{f} 201-209)$ & & & $\mathrm{PepO}_{200 / 201}{ }^{\mathrm{m}}$ \\
\hline $\mathrm{O}$ & $23.3-23.6$ & 787.5 & 787.9 & $\beta-\mathrm{CN}(\mathrm{fl}-6)$ & $\downarrow$ & $\downarrow$ & $\mathrm{CHY} / \mathrm{CEP}_{6 / 7}{ }^{\mathrm{j}, \mathrm{g}}$ \\
\hline $\mathrm{P}^{\mathrm{b}}$ & $24.4-24.6$ & 434.4 & 434.5 & $\alpha_{\mathrm{S} 1}-\mathrm{CN}(\mathrm{f} 21-23)$ & $\uparrow$ & $\uparrow$ & $\mathrm{PepO} / \mathrm{CHY}_{20 / 21}{ }^{\mathrm{h}, \mathrm{i}} ; \mathrm{CHY} / \mathrm{CEP}_{23 / 24}{ }^{\mathrm{g}}$ \\
\hline$Q^{b}$ & $24.6-24.8$ & 3133.2 & 3133.0 & $\alpha_{\mathrm{S} 2-\mathrm{CN}(\mathrm{f} 1-24) 4 \mathrm{P}}$ & $\uparrow$ & $\uparrow$ & $\mathrm{PLA}_{24 / 25^{\mathrm{g}}}$ \\
\hline $\mathrm{R}$ & $24.7-25.0$ & 2747.8 & 2747.6 & $\alpha_{\mathrm{S} 2}-\mathrm{CN}(\mathrm{fl}-21) 4 \mathrm{P}$ & $\uparrow$ & $\uparrow$ & $\mathrm{PLA}_{21 / 22}{ }^{\mathrm{g}}$ \\
\hline $\mathrm{S}$ & $25.2-25.4$ & 2619.2 & 2619.4 & $\alpha_{\mathrm{S} 2}-\mathrm{CN}(\mathrm{fl} 1-20) 4 \mathrm{P}$ & n.d. & $\uparrow$ & \\
\hline $\mathrm{T}$ & $26.0-26.2$ & 831.9 & 832.0 & $\alpha_{\mathrm{S} 2}-\mathrm{CN}(\mathrm{f} 175-181)$ & n.d. & - & $\mathrm{CHY} / \mathrm{CEP}_{174 / 175}{ }^{\mathrm{n}, \mathrm{g}} ; \mathrm{PLA}_{181 / 182^{\mathrm{g}}}$ \\
\hline $\mathrm{U}$ & $26.2-26.6$ & 1991.0 & 1991.3 & $\alpha_{\mathrm{S} 1}-\mathrm{CN}(\mathrm{f} 1-17)$ & $\uparrow$ & $\uparrow$ & $\mathrm{CEP}_{17 / 18^{g}} \mathrm{~g}$ \\
\hline $\mathrm{V}$ & $26.6-26.8$ & 2234.4 & 2234.6 & $\alpha_{\mathrm{S} 1-\mathrm{CN}(\mathrm{fl}-19)}$ & n.d. & $\uparrow$ & $\mathrm{PepO}_{19 / 20}{ }^{\mathrm{m}}$ \\
\hline $\mathrm{W}$ & $26.9-27.2$ & 933.3 & 933.1 & $\alpha_{\mathrm{S} 2-\mathrm{CN}(\mathrm{f} 175-182)}$ & n.d. & $\uparrow$ & 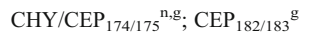 \\
\hline $\mathrm{X}$ & $27.9-28.1$ & 1198.2 & 1198.4 & k-CN(f96-105) & n.d. & $\uparrow$ & $\mathrm{CHY}_{95 / 96}{ }^{\circ} ; \mathrm{CHY}_{105 / 106}{ }^{\circ}$ \\
\hline Y & $28.2-28.7$ & 1877.2 & 1877.2 & $\alpha_{\mathrm{S} 1-\mathrm{CN}(\mathrm{f} 1-16)}$ & $\uparrow$ & $\uparrow$ & $\mathrm{CEP}_{16 / 17^{\mathrm{g}}}^{\mathrm{g}}$ \\
\hline Z & $28.7-29.0$ & 754.5 & 754.9 & $\alpha_{\mathrm{S} 1}-\mathrm{CN}(\mathrm{f} 10-16)$ & - & - & $\mathrm{CEP}_{9 / 10^{\mathrm{g}}}{ }^{\mathrm{g}} \mathrm{CEP}_{16 / 17^{\mathrm{g}}}{ }^{\mathrm{g}}$ \\
\hline Æ & $29.1-29.4$ & 2708.4 & 2708.5 & $\beta-\mathrm{CN}(\mathrm{f} 7-28) 4 \mathrm{P}$ & - & - & $\mathrm{CHY} / \mathrm{CEP}_{6 / 7}{ }^{\mathrm{j}, \mathrm{g}} ; \mathrm{PLA}_{28 / 29^{\mathrm{g}}}^{\mathrm{g}}$ \\
\hline
\end{tabular}


Table 5 (continued)

\begin{tabular}{|c|c|c|c|c|c|c|c|}
\hline \multirow[t]{2}{*}{ Peak $^{\mathrm{a}}$} & \multirow[t]{2}{*}{$\mathrm{RT}^{\mathrm{a}}(\min )$} & \multicolumn{2}{|l|}{ Mass (Da) } & \multirow[t]{2}{*}{ Assigned peptide } & \multicolumn{2}{|c|}{ Salt reduction ${ }^{\mathrm{c}}$} & \multirow[t]{2}{*}{ Suggested activity ${ }^{\mathrm{f}}$} \\
\hline & & Observed & Calculated & & 1 days & 30 days & \\
\hline \multirow[t]{2}{*}{$\varnothing$} & $31.4-31.7$ & 805.5 & 805.9 & $\alpha_{\mathrm{S} 1-\mathrm{CN}(\mathrm{f} 24-30)}$ & $\downarrow$ & $\downarrow$ & $\mathrm{CHY} / \mathrm{CEP}_{23 / 24^{\mathrm{g}}}$ \\
\hline & & 1555.8 & 1555.9 & $\alpha_{\mathrm{S} 1}-\mathrm{CN}(\mathrm{f} 102-114)$ & & & $\mathrm{CHY}_{101 / 102}{ }^{\mathrm{g}} ; \mathrm{CEP}_{114 / 115^{\mathrm{k}}}$ \\
\hline \multirow[t]{2}{*}{$\AA$} & $31.7-32.0$ & 2348.4 & 2347.7 & $\alpha_{\mathrm{S} 1}-\mathrm{CN}(\mathrm{fl} 1-20)$ & $\uparrow$ & $\uparrow$ & $\mathrm{PepO} / \mathrm{CHY}_{20 / 21}^{\mathrm{h}, \mathrm{i}}$ \\
\hline & & 2665.6 & 2665.4 & $\beta-\mathrm{CN}(\mathrm{fl}-21) 4 \mathrm{P}(m)$ & & & $\mathrm{CEP}_{21 / 22}{ }^{\mathrm{k}}$ \\
\hline AA & $32.5-32.7$ & 904.8 & 905.0 & $\alpha_{\mathrm{S} 1-\mathrm{CN}}(\mathrm{f} 17-23)$ & $\downarrow$ & $\uparrow$ & $\mathrm{CEP}_{16 / 17^{\mathrm{g}}}{ }^{\mathrm{g}} \mathrm{CHY} / \mathrm{CEP}_{23 / 24^{\mathrm{g}}}{ }^{\mathrm{g}}$ \\
\hline $\mathrm{AB}$ & $32.7-33.0$ & 790.8 & 790.9 & $\alpha_{\mathrm{S} 1}-\mathrm{CN}(\mathrm{f} 18-23)$ & $\downarrow$ & $\uparrow$ & $\mathrm{CEP}_{17 / 18}{ }^{\mathrm{g}} ; \mathrm{CHY} / \mathrm{CEP}_{23 / 24^{\mathrm{g}}}{ }^{\mathrm{g}}$ \\
\hline $\mathrm{AC}$ & $34.0-34.3$ & 3607.2 & 3606.6 & $\beta-\mathrm{CN}(\mathrm{fl}-29) 4 \mathrm{P}$ & $\uparrow$ & $\uparrow$ & $\operatorname{PLA}_{29 / 30}{ }^{\mathrm{p}}$ \\
\hline $\mathrm{AD}$ & $34.4-34.8$ & 3478.5 & 3478.4 & $\beta-\mathrm{CN}(\mathrm{f1}-28) 4 \mathrm{P}$ & $\uparrow$ & $\uparrow^{\mathrm{d}}$ & $\mathrm{PLA}_{28 / 29^{\mathrm{g}}}{ }^{\mathrm{g}}$ \\
\hline \multirow[t]{2}{*}{$\mathrm{AE}$} & $34.9-35.3$ & 3350.0 & 3350.2 & $\beta-\mathrm{CN}(\mathrm{f} 1-27) 4 \mathrm{P}$ & $\uparrow$ & $\uparrow$ & $\mathrm{CEP}_{27 / 28}{ }^{\mathrm{k}}$ \\
\hline & & 3977.1 & 3977.0 & $\beta-\mathrm{CN}(\mathrm{fl} 1-32) 4 \mathrm{P}$ & & & $\mathrm{CHY}_{32 / 33^{\mathrm{j}}}$ \\
\hline $\mathrm{AF}$ & $36.0-36.3$ & 1555.7 & 1555.8 & $\beta-\mathrm{CN}(\mathrm{f} 193-206)$ & n.d. & $\uparrow$ & 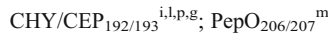 \\
\hline $\mathrm{AG}$ & $36.7-37.0$ & 1117.0 & 1117.3 & $\alpha_{\mathrm{S} 1}-\mathrm{CN}(\mathrm{f} 15-23)$ & n.d. & - & $\mathrm{PepO}_{14 / 15}{ }^{\mathrm{h}} ; \mathrm{CHY} / \mathrm{CEP}_{23 / 24}{ }^{\mathrm{g}}$ \\
\hline $\mathrm{AH}$ & $37.2-37.4$ & 4677.9 & 4677.6 & $\beta-\mathrm{CN}(\mathrm{f} 1-37) 5 \mathrm{P}$ & $\uparrow$ & $\uparrow$ & $\mathrm{CEP}_{37 / 38^{k, o}}$ \\
\hline $\mathrm{AI}$ & $37.4-37.7$ & 5407.5 & 5407.3 & $\beta-\mathrm{CN}(\mathrm{f1}-43) 5 \mathrm{P}$ & $\uparrow$ & $\uparrow$ & $\mathrm{CHY} / \mathrm{CEP}_{43 / 44^{\mathrm{j}, \mathrm{k}}}$ \\
\hline AJ & $37.7-37.9$ & 1246.4 & 1246.4 & $\alpha_{\mathrm{S} 1}-\mathrm{CN}(\mathrm{f} 14-23)$ & - & $\uparrow$ & $\mathrm{CEP}_{13 / 14^{\mathrm{g}}} ; \mathrm{CHY} / \mathrm{CEP}_{23 / 24}{ }^{\mathrm{g}}$ \\
\hline $\mathrm{AK}$ & $37.9-38.2$ & 3115.8 & 3115.8 & $\alpha_{\mathrm{S} 2}-\mathrm{CN}(\mathrm{f} 183-207)$ & n.d. & $\uparrow$ & $\mathrm{CEP}_{182 / 183^{\mathrm{g}}}{ }^{\mathrm{g}}$ \\
\hline $\mathrm{AL}$ & $39.1-39.4$ & 3718.6 & 3719.7 & $\beta-\mathrm{CN}(\mathrm{fl} 1-30) 4 \mathrm{P}$ & $\uparrow$ & $\uparrow$ & \\
\hline \multirow[t]{2}{*}{$\mathrm{AM}$} & $39.4-39.7$ & 1366.4 & 1366.6 & $\alpha_{\mathrm{S} 1}-\mathrm{CN}(\mathrm{f} 24-35)$ & n.d. & $\uparrow^{\mathrm{e}}$ & $\mathrm{CHY} / \mathrm{CEP}_{23 / 24^{g}} ; \mathrm{CEP}_{35 / 36}{ }^{\mathrm{k}}$ \\
\hline & & 1237.1 & 1237.5 & $\alpha_{\mathrm{S} 1}-\mathrm{CN}(\mathrm{f} 24-34)$ & & & $\mathrm{CHY} / \mathrm{CEP}_{23 / 24}{ }^{\mathrm{g}}$ \\
\hline AN & $39.7-40.0$ & 2764.2 & 2764.2 & $\alpha_{\mathrm{S} 1}-\mathrm{CN}(\mathrm{f} 1-23)$ & $\uparrow$ & $\uparrow$ & $\mathrm{CHY} / \mathrm{CEP}_{23 / 24}{ }^{\mathrm{g}}$ \\
\hline $\mathrm{AO}$ & $40.9-41.2$ & 6778.4 & 6778.4 & $\alpha_{\mathrm{S} 2}-\mathrm{CN}(\mathrm{f} 111-166) 3 \mathrm{P}$ & $\uparrow$ & $\uparrow$ & $\mathrm{CEP}_{166 / 167^{\mathrm{g}}}{ }^{\mathrm{g}}$ \\
\hline AP & $41.9-42.2$ & 4031.1 & 4030.9 & $\alpha_{\mathrm{S} 2-\mathrm{CN}(\mathrm{f} 175-207)}$ & $\uparrow$ & $\uparrow$ & $\mathrm{CHY} / \mathrm{CEP}_{174 / 175^{\mathrm{n}, \mathrm{g}}}$ \\
\hline $\mathrm{AQ}$ & $42.4-42.6$ & 6516.0 & 6515.6 & $\beta-\mathrm{CN}(\mathrm{fl}-52) 5 \mathrm{P}$ & $\uparrow$ & $\uparrow^{\mathrm{e}}$ & $\mathrm{CEP}_{52 / 53}{ }^{\mathrm{g}}$ \\
\hline $\mathrm{AR}$ & $42.6-42.8$ & 1052.3 & 1052.2 & $\alpha_{\mathrm{S} 1}-\mathrm{CN}(\mathrm{f} 24-32)$ & n.d. & $\uparrow^{\mathrm{e}}$ & $\mathrm{CHY} / \mathrm{CEP}_{23 / 24}{ }^{\mathrm{g}} ; \mathrm{CHY}_{32 / 33^{\mathrm{g}}}{ }^{\mathrm{g}}$ \\
\hline AS & $42.8-43.0$ & 5452.4 & 5451.6 & $\alpha_{\mathrm{S} 2}-\mathrm{CN}(\mathrm{f} 164-207)$ & - & - & $\mathrm{CHY}_{163 / 164}{ }^{\mathrm{n}}$ \\
\hline \multirow[t]{4}{*}{ AT } & $44.8-45.2$ & 7413.6 & 7412.9 & $\alpha_{\mathrm{S} 2}-\mathrm{CN}(\mathrm{f} 148-207)(m)$ & $\uparrow$ & $\uparrow$ & \\
\hline & & 1881.2 & 1881.3 & $\beta-\mathrm{CN}(\mathrm{f} 193-209)$ & & & 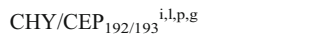 \\
\hline & & 7184.0 & 7183.6 & $\alpha_{\mathrm{S} 2}-\mathrm{CN}(\mathrm{f} 150-207)(m)$ & & & $\operatorname{PLA}_{149 / 150^{g}}{ }^{\mathrm{g}}$ \\
\hline & & 8226.3 & 8226.5 & $\beta-\mathrm{CN}^{\mathrm{A} 2}(\mathrm{f1}-68) 5 \mathrm{P}(m)$ & & & $\mathrm{CEP}_{68 / 69}{ }^{\mathrm{g}}$ \\
\hline $\mathrm{AU}$ & $45.2-45.5$ & 7056.0 & 7055.4 & $\alpha_{\mathrm{S} 2}-\mathrm{CN}(\mathrm{f} 151-207)$ & $\uparrow$ & $\uparrow$ & $\mathrm{PLA}_{150 / 151^{\mathrm{g}}}$ \\
\hline $\mathrm{AV}$ & $47.2-47.4$ & 2742.4 & 2742.3 & $\beta-\mathrm{CN}(\mathrm{f} 69-93)$ & - & $\uparrow$ & $\mathrm{CEP}_{68 / 69}{ }^{\mathrm{g}} ; \mathrm{CHY} / \mathrm{CEP}_{93 / 94}{ }^{1, \mathrm{~g}}$ \\
\hline $\mathrm{AW}$ & $49.2-49.5$ & 12482.4 & 12482.6 & $\beta-\mathrm{CN}^{\mathrm{A} 1+\mathrm{B}}(\mathrm{f} 1-107) 5 \mathrm{P}$ & $\uparrow$ & $\uparrow$ & $\mathrm{PLA}_{107 / 108^{\mathrm{g}}}$ \\
\hline \multirow[t]{2}{*}{$\mathrm{AX}$} & $49.6-50.0$ & 8983.0 & 8982.2 & $\beta-\mathrm{CN}^{\mathrm{A} 2}(\mathrm{f} 29-107) 1 \mathrm{P}$ & $\uparrow$ & $\uparrow$ & $\mathrm{PLA}_{28 / 29}{ }^{\mathrm{g}} ; \mathrm{PLA}_{107 / 108^{\mathrm{g}}}$ \\
\hline & & 7530.8 & 7530.4 & $\beta-\mathrm{CN}^{\mathrm{A} 1+\mathrm{B}}(\mathrm{f} 29-93) 1 \mathrm{P}$ & & & $\mathrm{PLA}_{28 / 29}{ }^{\mathrm{g}} ; \mathrm{CHY} / \mathrm{CEP}_{93 / 94}{ }^{1, \mathrm{~g}}$ \\
\hline \multirow[t]{5}{*}{ AY } & $50.0-50.9$ & 12217.5 & 12217.3 & $\beta-\mathrm{CN}^{\mathrm{A} 1+\mathrm{B}}(\mathrm{f} 1-105) 5 \mathrm{P}$ & $\uparrow$ & $\uparrow$ & $\mathrm{PLA}_{105 / 106}{ }^{\mathrm{g}}$ \\
\hline & & 12442.5 & 12442.6 & $\beta-\mathrm{CN}^{\mathrm{A} 2}(\mathrm{fl}-107) 5 \mathrm{P}$ & & & $\mathrm{PLA}_{107 / 108^{\mathrm{g}}}$ \\
\hline & & 10991.5 & 10990.8 & $\beta-\mathrm{CN}^{\mathrm{A} 1+\mathrm{B}}(\mathrm{fl}-93) 5 \mathrm{P}$ & & & $\mathrm{CHY} / \mathrm{CEP}_{93 / 94}{ }^{1, \mathrm{~g}}$ \\
\hline & & 8717.5 & 8716.9 & $\beta-\mathrm{CN}^{\mathrm{A} 2}(\mathrm{f} 29-105) 1 \mathrm{P}$ & & & $\mathrm{PLA}_{28 / 29}{ }^{\mathrm{g}} ; \mathrm{PLA}_{105 / 106}{ }^{\mathrm{g}}$ \\
\hline & & 7490.0 & 7490.4 & $\beta-\mathrm{CN}^{\mathrm{A} 2}(\mathrm{f} 29-93) 1 \mathrm{P}$ & & & $\mathrm{PLA}_{28 / 29}{ }^{\mathrm{g}} ; \mathrm{CHY} / \mathrm{CEP}_{93 / 94}{ }^{1, \mathrm{~g}}$ \\
\hline $\mathrm{AZ}$ & $50.9-51.3$ & 12177.6 & 12177.3 & $\beta-\mathrm{CN}^{\mathrm{A} 2}(\mathrm{fl}-105) 5 \mathrm{P}$ & $\uparrow$ & $\uparrow$ & $\mathrm{PLA}_{105 / 106^{\mathrm{g}}}{ }^{\mathrm{g}}$ \\
\hline
\end{tabular}


Table 5 (continued)

\begin{tabular}{|c|c|c|c|c|c|c|c|}
\hline \multirow[t]{2}{*}{ Peak $^{\mathrm{a}}$} & \multirow[t]{2}{*}{$\mathrm{RT}^{\mathrm{a}}(\min )$} & \multicolumn{2}{|l|}{ Mass (Da) } & \multirow[t]{2}{*}{ Assigned peptide } & \multicolumn{2}{|c|}{ Salt reduction ${ }^{\mathrm{c}}$} & \multirow[t]{2}{*}{ Suggested activity ${ }^{\mathrm{f}}$} \\
\hline & & Observed & Calculated & & 1 days & 30 days & \\
\hline \multirow[t]{2}{*}{$\mathrm{A} Æ$} & $51.3-51.8$ & 10950.8 & 10950.8 & $\beta-\mathrm{CN}^{\mathrm{A} 2}(\mathrm{fl}-93) 5 \mathrm{P}$ & $\uparrow$ & $\uparrow$ & $\mathrm{CHY} / \mathrm{CEP}_{93 / 94}{ }^{1, \mathrm{~g}}$ \\
\hline & & 9460.0 & 9460.8 & $\alpha_{\mathrm{S} 1}-\mathrm{CN}(\mathrm{f} 24-101) 8 \mathrm{P}$ & & & $\mathrm{CHY} / \mathrm{CEP}_{23 / 24^{\mathrm{g}}} ; \mathrm{CHY}_{101 / 102^{\mathrm{g}}}$ \\
\hline
\end{tabular}

CEP cell envelope-associated proteinase of Lactococcus, $C H Y$ chymosin, $C N$ casein, $m$ minor, $n . d$. MS signal not dominant, $P$ epO intracellular oligoendopeptidase, $P L A$ plasmin, $R T$ retention time

${ }^{a}$ Peak names and retention times refer to Fig. 3

${ }^{\mathrm{b}}$ Co-elution at day 1 . Area of single peak increases with decreasing salt content $(\uparrow)$

${ }^{c}$ A systematic increase and decrease in peak area as a function of decreasing salt content is denoted by $\uparrow$ and $\downarrow$, respectively

${ }^{\mathrm{d}}$ Peak area of low-salt cheese was larger than the rest, which all had similar areas

${ }^{\mathrm{e}}$ Peak area of high-salt cheese was smaller than the rest, which all had similar areas

${ }^{\mathrm{f}}$ Previous studies reporting cleavage sites of PLA, CEP, CHY and PepO

${ }^{\mathrm{g}}$ Sousa et al. (2001)

${ }^{\mathrm{h}}$ Exterkate and Alting (1995)

${ }^{\mathrm{i}}$ Exterkate et al. (1997)

${ }^{\mathrm{j}}$ Møller et al. (unpublished)

${ }^{\mathrm{k}}$ Reid and Coolbear (1999)

${ }^{1}$ Guillou et al. (1991)

${ }^{\mathrm{m}}$ Baankreis et al. (1995)

${ }^{\mathrm{n}}$ McSweeney et al. (1994)

${ }^{\text {o }}$ Reid et al. (1997)

${ }^{\mathrm{p}}$ Larsson et al. (2006)

the importance of $\alpha_{\mathrm{S} 1}-\mathrm{CN}(\mathrm{fl}-23)$ conversion by lactococcal CEP in the early phase production of amino acid $\mathrm{N}$ in cheese (Exterkate and Alting 1995). $\alpha_{\mathrm{S} 1}-\mathrm{CN}(\mathrm{fl}-9 / 13)$ (E/I) accumulated extensively during early ripening as shown previously (Broadbent et al. 2002) followed, soon after, by marked accumulations of additional starter CEP-derived $\alpha_{\mathrm{S} 1}-\mathrm{CN}$ N-terminal peptides, including $\alpha_{\mathrm{S} 1}-\mathrm{CN}(\mathrm{fl}-14 / 16 / 17)(\mathrm{J} / \mathrm{Y} / \mathrm{U})(\mathrm{Fig}$. 3, 30 days panel). Moreover, N-terminal degradation of $\alpha_{\mathrm{S} 1}-\mathrm{CN}$ produced $\alpha_{\mathrm{S} 1}-\mathrm{CN}(\mathrm{f1}-6 / 7 / 8 / 19 / 20)$ $(\mathrm{H} / \mathrm{F} / \mathrm{E} / \mathrm{V} / \AA)$ on much smaller scales. $\alpha_{\mathrm{S} 1}-\mathrm{CN}(\mathrm{fl}-23)$ accumulated during early ripening in accordance with the kinetics of the corresponding $\alpha_{\mathrm{S} 1-\mathrm{I}-\mathrm{CN}}$ and to markedly higher levels with decreasing salt content $(P<0.001$, Fig. $4 \mathrm{e})$. Subsequently, as intact $\alpha_{\mathrm{S} 1^{-}}$ $\mathrm{CN}$ levels vanished, so too did levels of $\alpha_{\mathrm{S} 1}-\mathrm{CN}(\mathrm{f1}-23)$, which along with a concomitant vast abundance of the corresponding CEP-derived C-terminal peptides of $\alpha_{\mathrm{S} 1}-\mathrm{CN}$ (f1-23) (Table 5; P/AA/AB/AG/AJ) brought further evidence that $\alpha_{\mathrm{S} 1}-\mathrm{CN}(\mathrm{fl}-23)$ in turn became rate limiting to starter CEP activity during early ripening.

Interestingly, the kinetics of the above-mentioned five major $\mathrm{N}$-terminal peptides of $\alpha_{\mathrm{S} 1}-\mathrm{CN}(\mathrm{f1}-23)$ degradation revealed substantially different salt dependencies (Fig. 4). Whereas formation of the earliest peptides $\alpha_{\mathrm{S} 1}-\mathrm{CN}(\mathrm{f1}-9 / 13)$ was stimulated by salt $(P<0.001)$, the opposite correlation was observed for $\alpha_{\mathrm{S} 1}-\mathrm{CN}(\mathrm{f1}-14 / 16 / 17)(P<0.001)$ (Figs. 3 and 4 ). The kinetics of $\alpha_{\mathrm{S} 1}-\mathrm{CN}(\mathrm{f} 1-16)$ strongly resembled that of 

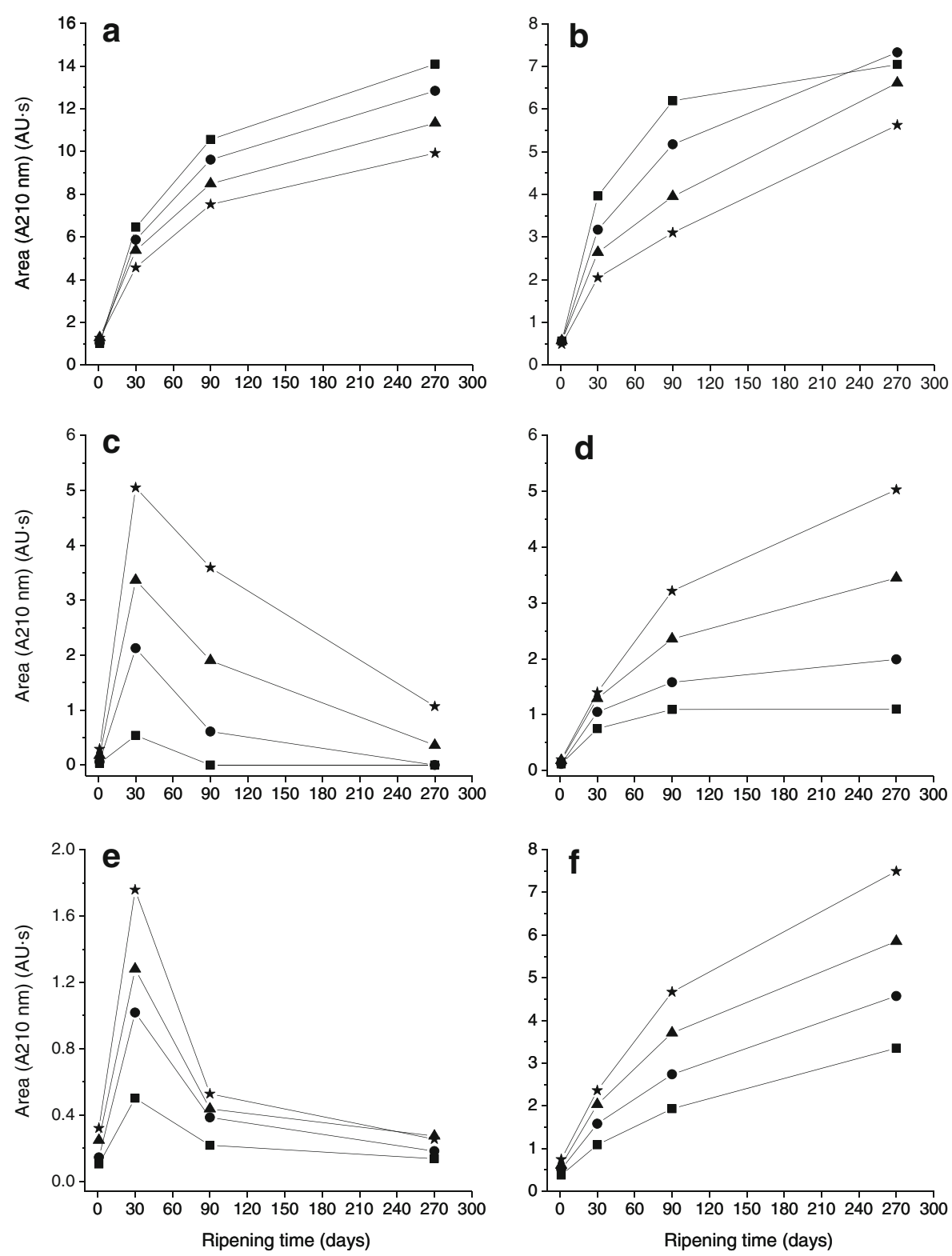

Fig. 4 Estimated development of $\alpha_{\mathrm{S} 1}-\mathrm{CN}(\mathrm{f1}-9)$ (E) (a), $\alpha_{\mathrm{S} 1}-\mathrm{CN}(\mathrm{f1}-13)$ (I) (b), $\alpha_{\mathrm{S} 1}-\mathrm{CN}(\mathrm{fl}-16)(\mathrm{J})$ (c), $\alpha_{\mathrm{S} 1}-\mathrm{CN}(\mathrm{fl} 1-14)(\mathrm{Y})(\mathbf{d})$ produced from starter CEP activity on $\alpha_{\mathrm{S} 1}-\mathrm{CN}(\mathrm{f1}-23)(\mathrm{AN})(\mathbf{e})$ and $\beta-\mathrm{CN}(\mathrm{f} 193-$ 209) (AT) (f) from chymosin activity during ripening of Cheddar made with a low $(0.9 \%)($ star $)$, reduced $(1.3 \%)$ (triangle), normal (1.8\%) (circle) or high (2.4\%) (square) level of salt. All peaks were markedly dominated of the respective peptide as evaluated by MS. Each data point represents the mean of duplicate cheese trials. Capital letter after peptides refers to Fig. 3. The effect of salt and ripening time on the amount of all six peptides was significant at $P<0.001$ after 30, 90 and 270 days and at all salt levels, respectively, and that of salt on $\alpha_{\mathrm{S} 1}-\mathrm{CN}(\mathrm{fl}-23)$ also at day $1 . \mathrm{HSD}=0.4,0.4,0.3,0.3,0.06$ and $0.8 \mathrm{AU} \cdot \mathrm{s}$ for $\alpha_{\mathrm{S} 1}-\mathrm{CN}(\mathrm{fl}-$ 9/13/14/16/23) and $\beta-\mathrm{CN}(\mathrm{f} 193-209)$, respectively 
$\alpha_{\mathrm{S} 1}-\mathrm{CN}(\mathrm{f1}-23)$, suggesting that substrate availability rather than salt concentration affected CEP activity towards $\alpha_{\mathrm{S} 1}-\mathrm{CN}_{16 / 17}$ cleavage. It follows from the effect of salt on early $\alpha_{\mathrm{S} 1}-\mathrm{CN}(\mathrm{f1}-9 / 13)$ accumulation that more $\alpha_{\mathrm{S} 1}-\mathrm{CN}(\mathrm{f1}-23)$ substrate was available for $\alpha_{\mathrm{S} 1}-\mathrm{CN}(\mathrm{fl}-16)$ formation at decreasing salt concentration. In contrast to $\alpha_{\mathrm{S} 1}-\mathrm{CN}$ (f1-16), levels of $\alpha_{\mathrm{S} 1}-\mathrm{CN}(\mathrm{f1}-9 / 13 / 14)$ increased throughout ripening. It is thus conceivable that $\alpha_{\mathrm{S} 1}-\mathrm{CN}(\mathrm{f1}-16)$ acted as secondary substrate to starter CEP activity, as supported by the considerable accumulation of e.g. $\alpha_{\mathrm{S} 1}-\mathrm{CN}(\mathrm{f10}-16)(\mathrm{Z})$ (Figs. 3 and 4).

Even though twenty-three out of thirty-three identified $\alpha_{\mathrm{S} 1}-\mathrm{CN}$ peptides originated from utilisation of $\alpha_{\mathrm{S} 1}-\mathrm{CN}(\mathrm{f} 1-23)$ as detailed above, $\alpha_{\mathrm{S} 1}-\mathrm{CN}(\mathrm{f} 31-35)(\mathrm{G})$ and $\alpha_{\mathrm{S} 1}$ $\mathrm{CN}(\mathrm{f} 24-30 / 32 / 34 / 35)(\varnothing / \mathrm{AM} / \mathrm{AR})$ and $\alpha_{\mathrm{S} 1}-\mathrm{CN}(\mathrm{f} 99-100 / 101)(\mathrm{B} / \mathrm{N})$ were identified from the $\mathrm{N}$ - and $\mathrm{C}$-terminal of $\alpha_{\mathrm{S} 1}-\mathrm{CN}(\mathrm{f} 24-101)$ respectivley, whereas only $\alpha_{\mathrm{S} 1}-\mathrm{CN}$ (f102-114) (Ø) was identified from $\alpha_{\mathrm{S} 1}-\mathrm{CN}(\mathrm{f1} 102-199)$. Chymosin, CEP and perhaps intracellular enzyme activities were involved in the production of those peptides, which were affected differently by the salt concentration (Table 5).

While $\alpha_{\mathrm{S} 1}$-CN peptides originated from the major chymosin-derived casein fragments, the majority of $\beta-\mathrm{CN}$ peptides were formed from plasmin-derived fragments (Table 5). However, due to the overall resistance of $\beta-\mathrm{CN}$ to hydrolysis, these peptides were generally less prevalent as compared to $\alpha_{\mathrm{S} 1}-\mathrm{CN}$ peptides, except for the accumulation of $\beta-\mathrm{CN}(\mathrm{f193}-209)$ (AT) representing the highly hydrophobic C-terminal product of primary chymosin activity (Figs. 3 and 4f). It is noted, however, that co-elution with particularly $\alpha_{\mathrm{S} 2}-\mathrm{CN}(\mathrm{f148}-207)$ caused an overestimation of the net increase in the concentration of $\beta-\mathrm{CN}(\mathrm{f193-209)}$ during ripening at all salt levels (Table 5). Broadbent et al. (2002) reported a slight increase during 6 months ripening of reduced-fat Cheddar cheese. This important, bitter peptide was formed initially in all cheeses, yet at a markedly higher rate with decreasing salt content $(P<0.001)$, which largely ascribes aforementioned effect of salt on $\beta-\mathrm{CN}$ degradation to chymosin activity and agrees with earlier observations on variable $\mathrm{S} / \mathrm{M}$ levels in Cheddar (Kelly et al. 1996).

Several early $\beta-\mathrm{CN}$ peptides originated from $\beta-\mathrm{CN}(\mathrm{fl}-28)$ and were mostly ascribed to lactococcal CEP activity (Table 5; D/L/O/Æ $/ \AA / A E$ ). Salt was indicated to stimulate $\beta-\mathrm{CN}_{6 / 7}$ cleavage, whereas the effect on other activities was less conclusive due to co-elution. Additional seven large $\mathrm{N}$-terminal peptides of $\beta-\mathrm{CN}$ containing plasmin cleavage site $\beta-\mathrm{CN}_{28 / 29}(\beta-\mathrm{CN}(\mathrm{f} 1-30 / 32 / 37 / 43 / 52 / 68 / 93)$; AL/AE/AH/ $\mathrm{AI} / \mathrm{AQ} / \mathrm{AT} / \mathrm{AY}, \mathrm{A} Æ)$ suggested chymosin and/or starter CEP to actively hydrolyse peptide bonds of proteose peptone components $\beta-\mathrm{CN}(\mathrm{fl}-105 / 7)(\mathrm{AY} / \mathrm{AW} / \mathrm{AZ})$ and/or intact $\beta-\mathrm{CN}$. Decreasing salt concentration generally supported the formation of these peptides.

Early $\alpha_{\mathrm{S} 2}-\mathrm{CN}$ peptides were well-represented in the $\mathrm{pH} 4$ 4-6-soluble extracts relative to the composition of whole casein. Thus, five $\mathrm{N}$-terminal $(\mathrm{K} / \mathrm{M} / \mathrm{Q} / \mathrm{R} / \mathrm{S})$, nine $\mathrm{C}$-terminal $(\mathrm{L} / \mathrm{T} / \mathrm{W} /$ AK/AP/AS/AT/AU) and one internal peptide(s) (AO) were identified (Fig. 3). N-terminal peptides derived from plasmin activity, whereas plasmin, chymosin and CEP activities produced the $\mathrm{C}$-terminal peptides. $\alpha_{\mathrm{S} 2}-\mathrm{CN}$ peptides appeared generally more abundant at decreasing levels of salt (Table 5).

Only k-CN(f96-105) (X) from para-k-CN showed early dependency on salt. This peptide was formed by chymosin activity and was found in amounts inversely correlated with the salt content of 30-day-old cheeses (Table 5). 


\subsection{Amino acid accumulation}

The total amount of free amino acids (FAA) increased steadily throughout ripening regardless of the salt content $(P<0.001)$ but reached significant levels only after 270 days that correlated positively with salt concentration $(P<0.001)$ (45 to $70 \mathrm{mmol} \cdot \mathrm{kg}^{-1}$ ) (Fig. 5). However, while the ripened high-salt cheese contained particularly more FAA than the rest, all levels remained relatively low. This can be explained by the use of a starter with a low level of autolysis, the absence of any adjunct culture and a low ripening temperature $\left(9^{\circ} \mathrm{C}\right)$, amongst other parameters. The concentration of all individual amino acids except Arg and Glu increased during the entire period of ripening. Concomitant accumulations of citrulline and ornithine and of $\gamma$-amino butyric acid suggested the net catabolism of Arg and Glu to be attributed to deiminase and decarboxylase activity, respectively (not shown).

\section{Discussion}

In this section, we aim to facilitate a deeper understanding of cause and effect related to salt variation in Cheddar cheese by taking a multivariate approach. For this purpose, latent structures within a selection of thirty-three biochemical variables measured during ripening were visualised by the scores and loadings of a PCA model (Fig. 6). A simple 2-D principal components (PC) space appears to efficiently discriminate the cheese samples according to ripening time (PC1) and salt concentration (PC2) using 47 and $26 \%$ of the total variance, respectively (Fig. 6a). The scores plot reveals an overall high replicate similarity, and hence, PC trajectories representing the biochemical ripening profiles at each salt level can be drawn. These trajectories illustrate that all cheeses develop in a similar direction during ripening (i.e. positively along PC1), whereas cheeses of different salt content diversify during the first 30 days of ripening according to the direction of PC2. Altogether, the trajectory of high-salt cheese appears particularly accelerated towards the top-right corner, and as a result, these cheeses obtain higher PC2 scores after 270 days (Fig. 6a). As revealed by the PCA

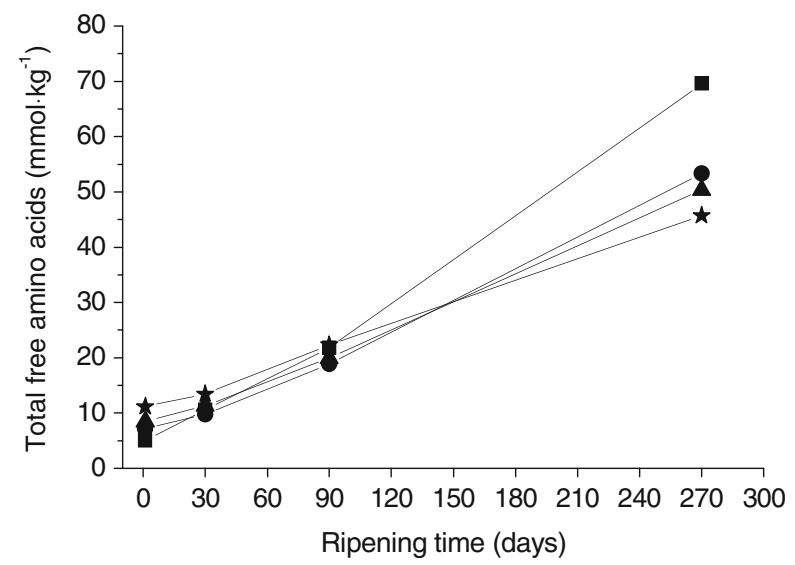

Fig. 5 Development in the concentration of total free amino acids during ripening of Cheddar made with a low (0.9\%) (star), reduced (1.3\%) (triangle), normal (1.8\%) (circle) or high (2.4\%) (square) level of salt. Each data point represents the mean of duplicate cheese trials. The effect of salt and ripening time was significant at $P<0.001$ after 270 days and at all salt levels, respectively. $\mathrm{HSD}=6.1 \mathrm{mmol} \cdot \mathrm{kg}^{-1}$ 

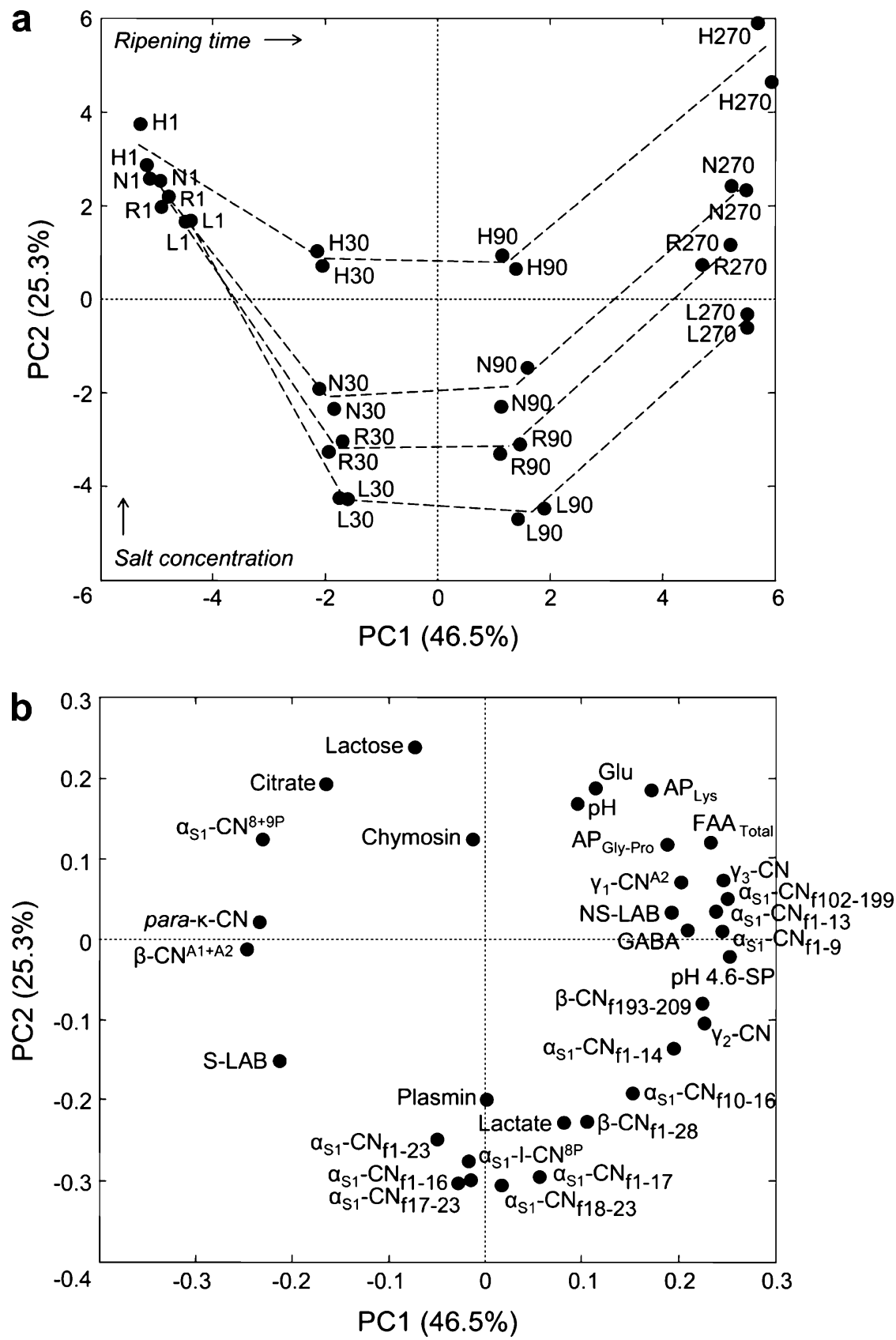

Fig. 6 PCA scores trajectories (a) and loadings (b) of thirty-two Cheddar samples and thirty-three response variables in the first and second PCs. Bracketed numbers at axis labels refer to percent explained variance by the respective PC of the total variance in the data-set. $L$ low- $(0.9 \%), R$ reduced- $(1.3 \%), N$ normal- $(1.8 \%)$ and $H$ high-salt cheese $(2.4 \%)$. Number in sample names in scores plot refers to $1,30,90$ and 270 days of ripening. $A P$ aminopeptidase, $F A A$ free amino acid, $G A B A \gamma$-amino butyric acid, $N S$-/S$L A B$ non-starter/starter lactic acid bacteria, $p H$ 4.6-SP index of total $\mathrm{pH}$ 4.6-soluble peptides 
loadings, markers of maturity contribute the most to the combined positive PC1 and PC2 directions and include higher $\mathrm{pH}$, cell lysis, Glu and total amounts of FAA (Fig. 6b). In addition, higher levels of lactose, citrate, intact $\alpha_{\mathrm{S} 1}-\mathrm{CN}$ and chymosin activity contribute to characterising cheeses of increasing salt content during (early) ripening. In contrast, the biochemical profiles of cheeses with decreasing salt content had higher contributions during the course of ripening from S-LAB counts, lactate, $\alpha_{\mathrm{S} 1}-\mathrm{I}-\mathrm{CN}, \alpha_{\mathrm{S} 1^{-}}$ $\mathrm{CN}(\mathrm{f} 1-23)$ and most of its degradation products, plasmin activity, $\beta-\mathrm{CN}(\mathrm{f} 1-28)$ and $\beta-\mathrm{CN}(\mathrm{f} 193-209)$, i.e. markers related to early stage ripening or immaturity. Besides, it is interesting to note that $\alpha_{\mathrm{S} 1}-\mathrm{CN}(\mathrm{fl} 1-23)$ and derived $\mathrm{N}$ - and $\mathrm{C}$ terminal peptides $\left(\alpha_{\mathrm{S} 1}-\mathrm{CN}(\mathrm{f} 1-16 / 17)\right.$ and $\left.\alpha_{\mathrm{S} 1}-\mathrm{CN}(\mathrm{f} 17 / 18-23)\right)$ load closely to one another. Hence, all of these peptides follow a similar kinetics and salt dependency and the $\mathrm{C}$ terminal peptides too are metabolised by the starter, the net sequence of events being somewhat delayed in time relative to $\alpha_{\mathrm{S} 1}-\mathrm{CN}(\mathrm{f1}-23)$. If not used as a secondary substrate by starter CEP, on the contrary, N-terminal peptides accumulate extensively throughout ripening $\left(\alpha_{\mathrm{S} 1}-\mathrm{CN}(\mathrm{f} 1-9 / 13 / 14)\right)$, although presumably susceptible to hydrolysis by X-Pro dipeptidyl AP.

In essence, the major biochemical impact of salt reduction as summarised by PCA translates into extensive casein degradation by the concerted action of plasmin, chymosin and starter CEP producing large amounts of $\mathrm{pH}$ 4.6-SP that were not adequately removed by microbial peptidases to release FAA. Similarly, results by Kelly et al. (1996) indicated higher and lower levels of water- and PTA-soluble N, respectively, during ripening of Cheddar at decreasing S/M levels. The further hydrolysis of medium and small-sized peptides plays a pivotal role in cheese ripening partly because they themselves may possess low bitterness thresholds and partly because their constituent FAA contribute directly and indirectly (by acting as precursors of volatile flavour compounds) to the flavour profile of mature Cheddar (Sousa et al. 2001). The excessive formation of the bitter peptide $\beta-\mathrm{CN}(\mathrm{f193}-209)$ upon salt reduction represents a clear example of this proteolytic imbalance (Fig. 4f). The inhibitory effect of salt on $\beta-\mathrm{CN}$ hydrolysis is described in the literature to relate to ionic strength-induced conformational changes of the protein favouring hydrophobic interaction and, hence, restricted accessibility to cleavage sites even at a low ionic strength, rather than to the activity of chymosin per se. This indirect impact of salt on in situ chymosin activity is reflected by the inverse relationship between assayed residual chymosin and levels of chymosin-derived peptides, e.g. $\beta-\mathrm{CN}(\mathrm{f193}-209)$, along PC2 (Fig. 6b). Once formed, $\beta-\mathrm{CN}(\mathrm{f1} 193-$ 209 ) is highly resistant to degradation by both chymosin and CEP, whereas it can be cleaved at several sites by an intracellular endopeptidase ( $\beta-\mathrm{CN}(\mathrm{f} 193-206)$, Table 5; AF), which attains easy substrate availability upon cell lysis (Baankreis et al. 1995; Exterkate et al. 1997). Salt reduction correlated with lower levels of lysis resulting in insufficient degradation of $\beta-\mathrm{CN}(\mathrm{f193}-209)$ that reinforced the effect of salt on its accumulation, and lower amounts of FAA (Figs. 2 and 5). FAA release in cheese depends almost exclusively on intracellular peptidase activity and may, as a consequence, be facilitated considerably upon leakage of these enzymes into the cheese matrix due to lysis of the bacterial cell (Hannon et al. 2003). Lower bitterness intentisy and concentration of $\beta-\mathrm{CN}(\mathrm{f} 193-209)$ were demonstrated in Cheddar made with a lytic starter culture (Soeryapranata et al. 2002). Likewise, less bitter Cheddar was obtained by using less IMCU of a coagulant (camel chymosin) with less activity towards $\beta-\mathrm{CN}_{192 / 193}$ than normal bovine chymosin (Bansal et al. 2009b). 
Compensation of salt reduction in Cheddar thus warrants remedies to counterbalance such proteolytic profile, i.e. by decelerating proteinase while accelerating peptidase activities in the cheese. Noteworthy, however, is the large increase in total $\mathrm{pH}$ 4.6-SP throughout ripening and low FAA concentrations across all of the ripened cheeses indicating overall low levels of peptidase activity/cheese maturity (Table 4; Fig. 5). Consequently, the balanced ratio of peptidase to proteinase activity would appear to follow a trajectory beyond that of the high-salt cheese.

A general qualitative agreement was found between the effects of salt detailed in the present study and those of the ratio of $\mathrm{S} / \mathrm{M}$ investigated previously (Kelly et al. 1996; Rulikowska et al. 2008; Thomas and Pearce 1981). However, a concomitant increase in the level of moisture would appear to reinforce these effects as the ratio of $\mathrm{S} / \mathrm{M}$ constitutes one of the principal determinants of the water activity in cheese (Guinee and Fox 2004). The concept of moisture equalisation by means of adjusted manufacture technology thus works to narrow the gap of salt compensation and should as such be considered as an important step towards successful salt reduction in ripened cheese. Furthermore, although the use of higher temperature stress during low-salt cheese manufacture did not cause any significant additional starter lysis in the present trial (Fig. 2, day 1), this result is likely to be starter specific and hence, such elevated cooking treatment may indeed cause higher levels of lysis of other, less thermally robust starter cultures. The approach of introducing a controlled level of lysis represents one means of increasing the ratio of peptidase to proteinase activity in the cheese and has demonstrated a potential to accelerate ripening and counteract bitterness development (Hannon et al. 2003; Lowrie et al. 1972). The 270-day-old cheeses of this study are currently being characterised in terms of physicochemical and sensory properties.

\section{Conclusion}

Cheddar containing $0.9,1.3,1.7$ or $2.4 \%(w / w)$ salt and equal levels of moisture $(37.7 \pm 0.2 \%(w / w))$ could be manufactured by parallel adjustment of the curd grain size, cooking temperature and time, cheddaring, curd chip size and rate of salting. Over the course of 270 days ripening, salt reduction caused chymosin activity to accelerate casein degradation. Lactococcal CEP-derived peptides of $\alpha_{\mathrm{S} 1}-\mathrm{CN}(\mathrm{f1}-23)$ accumulated at rates that correlated positively or inversely with salt concentration. Lower levels of starter lysis accumulated lower amounts of FAA upon salt reduction. Although affected by cooking treatment and $\mathrm{pH}$ differences, the action of plasmin appeared of less significance, due to low levels of $\mathrm{pH}$ across all cheeses. Overall, salt reduction caused a marked decrease in the ratio of peptidase to proteinase activity resulting in excessive formation and simultaneous insufficient degradation of bitter peptides $(\beta-\mathrm{CN}(\mathrm{f} 193-209))$ and a low stage of maturity. The ability to counterbalance this ratio appeared central to successful salt compensation. Salt reduction generally manifested as quantitative effects implying that the salt content of Cheddar may be significantly reduced without altering the cheese identity. Moisture adjustment narrowed the gap of salt compensation, thus serving as a first remedy to be adopted in any attempt to produce high-quality salt-reduced Cheddar. 
Acknowledgments This work was funded partly by a Ph.D. scholarship from the Faculty of Life Sciences, University of Copenhagen and partly by Chr. Hansen A/S. We thank Anders Sørensen and Brian Rasmussen (Chr. Hansen A/S) for expert assistance and great endurance during cheese manufacture, Anni Bager, Pia Pedersen and Jacob Stang for skilled help with amino acid and peptide analyses and Ib Skovgaard, Bo Markussen and Frans van den Berg (all University of Copenhagen) for statistical advices.

\section{References}

Ardö Y, Polychroniadou A (1999) Laboratory manual for chemical analysis of cheese. European Communities, Office for Official Publications of the European Communities, Luxembourg

Ardö Y, Mansson HL, Hedenberg A, Larsson PO (1989) Studies of peptidolysis during early maturation and its influence on low-fat cheese quality. Milchwissenschaft 44:485-495

Baankreis R, van Schalkwijk S, Alting AC, Exterkate FA (1995) The occurrence of two intracellular oligoendopeptidases in Lactococcus lactis and their significance for peptide conversion in cheese. Appl Microbiol Biotechnol 44:386-392

Bansal N, Fox PF, McSweeney PLH (2009a) Comparison of the level of residual coagulant activity in different cheese varieties. J Dairy Res 76:290-293

Bansal N, Drake MA, Piraino P, Broe ML, Harboe M, Fox PF, McSweeney PLH (2009b) Suitability of recombinant camel (Camel dromedarius) chymosin as a coagulant for Cheddar cheese. Int Dairy J 19:510-517

Broadbent JR, Barnes M, Brennand C, Strickland M, Houck K, Johnson ME, Steele JL (2002) Contribution of Lactococcus lactis cell envelope proteinase specificity to peptide accumulation and bitterness in reduced-fat Cheddar cheese. Appl Environ Microbiol 68:1778-1785

Bütikofer U, Ardö Y (1999) Quantitative determination of free amino acids in cheese. In: IDF General Secretariat (ed) Chemical methods for evaluating proteolysis in cheese maturation (part 2). Bulletin no. 337 of the International Dairy Federation. International Dairy Federation, Brussels, pp 24-32

Cruz AG, Faria JAF, Pollonio MAR, Bolini HMA, Celeghini RMS, Granato D, Shah NP (2011) Cheeses with reduced sodium content: effects on functionality, public health benefits and sensory properties. Trends Food Sci Tech 22:276-291

Exterkate FA, Alting AC (1995) The role of starter peptidases in the initial proteolytic events leading to amino acids in Gouda cheese. Int Dairy J 5:15-28

Exterkate FA, Lagerwerf FM, Haverkamp J, van Schalkwijk S (1997) The selectivity of chymosin action on $\alpha_{\mathrm{S} 1}$ - and $\beta$-caseins in solution is modulated in cheese. Int Dairy $\mathrm{J}$ 7:47-54

Guillou H, Miranda G, Pelissier J-P (1991) Hydrolysis of $\beta$-casein by gastric proteases. I. Comparison of proteolytic action of bovine chymosin and pepsin A. Int J Peptide Protein Res 37:494-501

Guinee TP, Fox PF (2004) Salt in cheese: physical, chemical and biological aspects. In: Fox PF, McSweeney PLH, Cogan TM, Guinee TP (eds) Cheese: chemistry, physics and microbiology, Volume 1: general aspects. Elsevier Academic, San Diego, pp 207-259

Hannon JA, Wilkinson MG, Delahunty CM, Wallace JM, Morrissey PA, Beresford TP (2003) Use of autolytic starter systems to accelerate the ripening of Cheddar cheese. Int Dairy J 13:313-323

Intersalt Cooperative Research Group (1988) Intersalt: an international study of electrolyte excretion and blood pressure. Results of $24 \mathrm{~h}$ urinary sodium and potassium excretion. BMJ 297:319-328

ISO5534:IDF4 (2004) Cheese and processed cheese-determination of the total solids content (reference method). International Dairy Federation, Brussels

ISO5943:IDF88 (2006) Cheese and processed cheese products-determination of chloride contentpotentiometric titration method. International Dairy Federation, Brussels

ISO21543:IDF201 (2006) Milk products_-guidelines for the application of near infrared spectrometry. International Dairy Federation, Brussels

ISO11815:IDF157 (2007) Milk-determination of total milk-clotting activity of bovine rennets. International Dairy Federation, Brussels

Kelly M, Fox PF, McSweeney PLH (1996) Effect of salt-in-moisture on proteolysis in Cheddar-type cheese. Milchwissenschaft 51:498-501

Larsson M, Zakora M, Dejmek P, Ardö Y (2006) Primary proteolysis studied in a cast cheese made from microfiltered milk. Int Dairy J 16:623-632 
Lawrence RC, Gilles J, Creamer LK, Crow VL, Heap HA, Honoré CG (2004) Cheddar cheese and related drysalted cheese varieties. In: Fox PF, McSweeney PLH, Cogan TM, Guinee TP (eds) Cheese: chemistry, physics and microbiology. Volume 2: major cheese groups. Elsevier Academic, San Diego, pp 71-102

Lowrie RJ, Lawrence RC, Pearce LE, Richards EL (1972) Cheddar cheese flavour. III. The growth of lactic streptococci during cheesemaking and the effect on bitterness development. N Z J Dairy Sci Technol 7:44-50

McSweeney PLH, Fox PF (2004) Metabolism of residual lactose and of lactate and citrate. In: Fox PF, McSweeney PLH, Cogan TM, Guinee TP (eds) Cheese: chemistry, physics and microbiology, volume 1: general aspects. Elsevier Academic, San Diego, pp 361-371

McSweeney PLH, Olson NF, Fox PF, Healy A (1994) Proteolysis of bovine $\alpha_{\mathrm{S} 2}$-casein by chymosin. Z Lebensm Unters Forsch 199:429-432

Reid JR, Coolbear T (1999) Specificity of Lactococcus lactis subsp. cremoris SK11 proteinase, lactocepin III, in low-water-activity, high-salt-concentration humectant systems and its stability compared with that of lactocepin I. Appl Environ Microbiol 65:2947-2953

Reid JR, Coolbear T, Ayers JS, Coolbear KP (1997) The action of chymosin on K-casein and its macropeptide: effect of $\mathrm{pH}$ and analysis of products of secondary hydrolysis. Int Dairy J 7:559-569

Richardson BC, Pearce KN (1981) The determination of plasmin in dairy products. N Z J Dairy Sci Technol 16:209-220

Rulikowska A, Kilcawley KN, Doolan I, Alonso-Gomez M, Beresford TP, Wilkinson MG (2008) Influence of sodium chloride on the quality of Cheddar cheese. In: Poster from the 5th IDF symposium on cheese ripening, Bern. http://www.cheese2008.ch/download.php?filename=Kilcawley_2.pdf. Accessed 1 Nov 2011

Schroeder CL, Bodyfelt FW, Wyatt CJ, McDaniel MR (1988) Reduction of sodium chloride in Cheddar cheese: effect on sensory, microbiological, and chemical properties. J Dairy Sci 71:2010-2020

Soeryapranata E, Powers JR, Fajarrini F, Weller KM, Hill HH, Siems WF (2002) Relationship between MALDI-TOF analysis of $\beta-\mathrm{CN}$ f193-209 concentration and sensory evaluation of bitterness intensity of aged Cheddar cheese. J Agric Food Chem 50:4900-4905

Sousa MJ, Ardö Y, McSweeney PLH (2001) Advances in the study of proteolysis during cheese ripening. Int Dairy J 11:327-345

Stadhouders J, Hup G, van der Waals CB (1977) Determination of calf rennet in cheese. Neth Milk Dairy J $31: 3-15$

Thomas TD, Pearce KN (1981) Influence of salt on lactose fermentation and proteolysis in Cheddar cheese. N Z J Dairy Sci Technol 16:253-259

Webster JL, Dunford EK, Hawkes C, Neal BC (2011) Salt reduction initiatives around the world. J Hypertens 29:1043-1050

Wilkinson MG, Guinee TP, Fox PF (1994) Factors which may influence the determination of autolysis of starter bacteria during Cheddar cheese ripening. Int Dairy J 4:141-160 